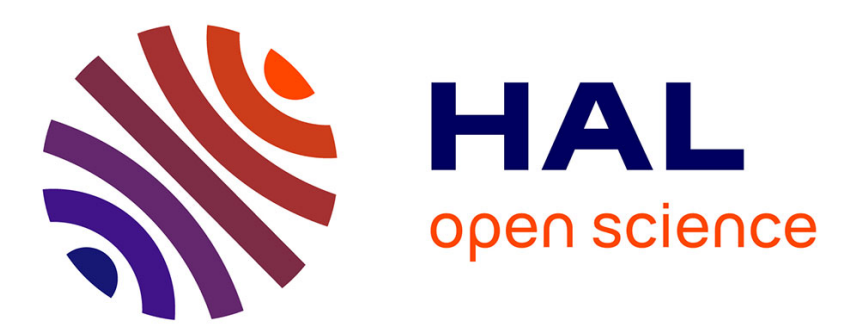

\title{
Peripherally Metalated Porphyrins with Applications in Catalysis, Molecular Electronics and Biomedicine
}

\author{
Jean-François Longevial, Sébastien Clément, Jennifer Wytko, Romain
}

Ruppert, Jean Weiss, Sébastien Richeter

\section{- To cite this version:}

Jean-François Longevial, Sébastien Clément, Jennifer Wytko, Romain Ruppert, Jean Weiss, et al.. Peripherally Metalated Porphyrins with Applications in Catalysis, Molecular Electronics and Biomedicine. Chemistry - A European Journal, 2018, 24 (58), pp.15442-15460. 10.1002/chem.201801211. hal-01898530

\section{HAL Id: hal-01898530 \\ https://hal.science/hal-01898530}

Submitted on 16 Jan 2019

HAL is a multi-disciplinary open access archive for the deposit and dissemination of scientific research documents, whether they are published or not. The documents may come from teaching and research institutions in France or abroad, or from public or private research centers.
L'archive ouverte pluridisciplinaire HAL, est destinée au dépôt et à la diffusion de documents scientifiques de niveau recherche, publiés ou non, émanant des établissements d'enseignement et de recherche français ou étrangers, des laboratoires publics ou privés. 


\section{Antitumour Agents |Reviews Showcase|}

\section{Peripherally Metalated Porphyrins with Applications in Catalysis,} Molecular Electronics and Biomedicine

Jean-François Longevial, ${ }^{[a]}$ Sébastien Clément, ${ }^{[a]}$ Jennifer A. Wytko, ${ }^{[b]}$ Romain Ruppert, $^{[b]}$ Jean Weiss, ${ }^{[b]}$ and Sébastien Richeter ${ }^{*[a]}$
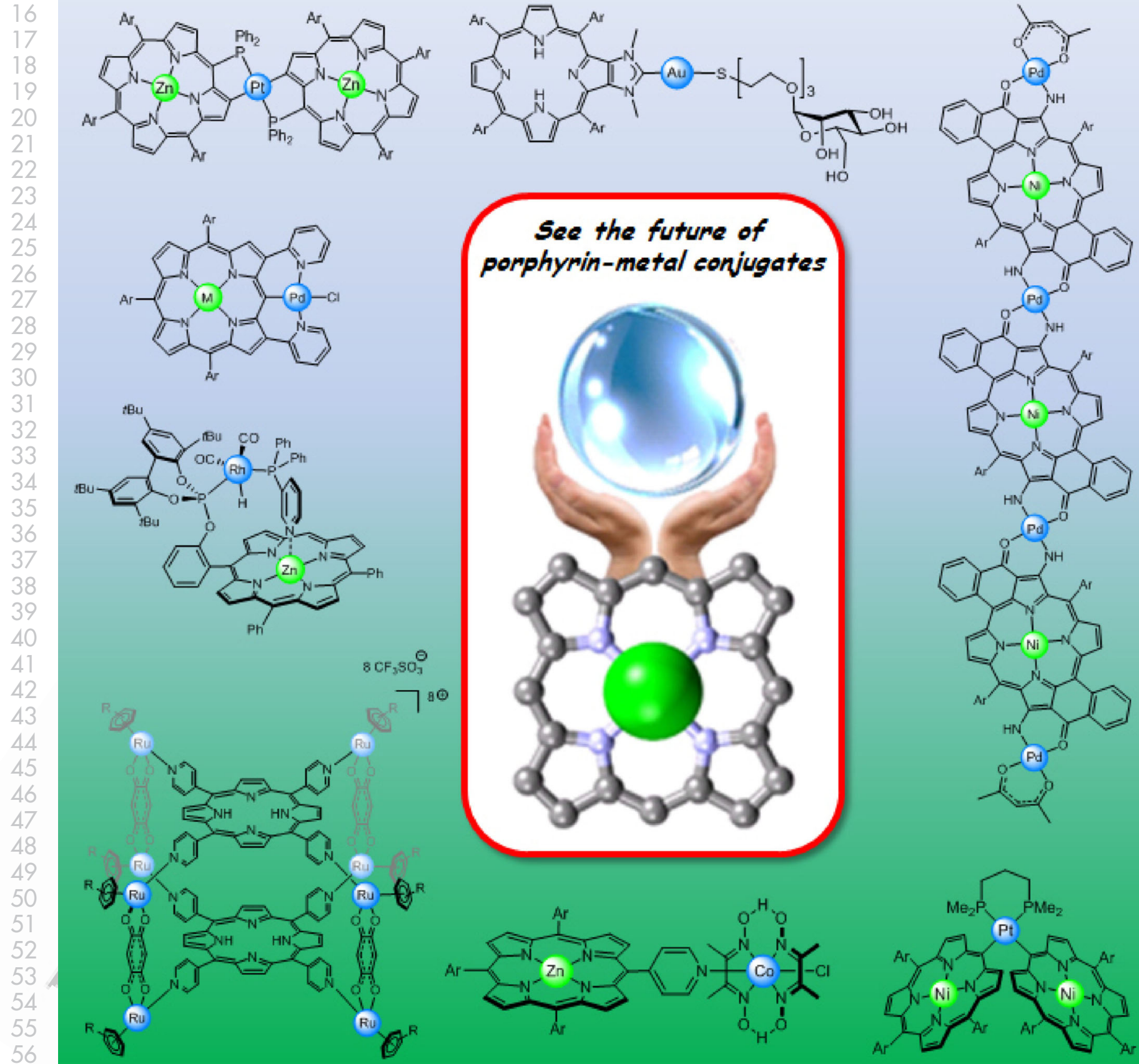
Abstract: Porphyrins are conjugated, stable chromophores with a central core that binds a variety of metal ions and an easily functionalized peripheral framework. By combining the catalytic, electronic or cytotoxic properties of selected transition metal complexes with the binding and electronic properties of porphyrins, enhanced characteristics of the en- semble are generated. This review article focuses on porphyrins bearing one or more peripheral transition metal complexes and discusses their potential applications in catalysis or biomedicine. Modulation of the electronic properties and intramolecular communication through coordination bond linkages in bis-porphyrin scaffolds is also presented.

\section{Introduction}

Natural porphyrins and their congeners, such as chlorins and bacteriochlorins, are considered as "pigments of life" because they are known to play significant roles in important biological processes such as photosynthesis (role of chlorophylls in photosynthetic systems), ${ }_{1}^{[1]}$ the transport and storage of molecular oxygen (role of hematoporphyrins in blood hemoglobin and myoglobin, respectively) ${ }^{[2]}$ or catalytic oxidation reactions (role of cytochrome P-450 enzymes). ${ }^{[3]}$ Inspired by Nature, the chemistry of tetrapyrrolic macrocyles, such as porphyrins, phthalocyanines, porphyrazines or corroles, has rapidly grown during the last fifty years and a large variety of porphyrin derivatives are now reported in the literature. The term "metalloporphyrins" (and metal complexes of related phthalocyanines, porphyrazines or corroles) usually refers to compounds where the metal ions are coordinated within the internal cavity. The inner metal in the porphyrin core can play various roles depending on the targeted applications. It can be used as a catalytic site or as a coordination site for the construction of multiporphyrinic systems ranging from finite dimeric species to infinite polymeric materials. ${ }^{[4]}$

Continuous advances in the functionalization of the $\beta$-pyrrolic and meso positions of porphyrins led to the synthesis of numerous porphyrinoids bearing peripheral coordination sites in addition to the classical inner coordination site. ${ }^{[5]}$ These compounds offer new opportunities to anchor metal complexes at the periphery of porphyrins. Some core-modified porphyrinoids, such as $\mathrm{N}$-confused porphyrins ${ }^{[6]}$ and porphyrazines, ${ }^{[5]}$ possess nitrogen atoms in place of carbon atoms at their periphery. Although these nitrogen atoms can be used to anchor peripheral metal complexes, these fascinating compounds are not discussed in this review that focuses on porphyrins only. Moreover, only porphyrins containing peripheral transition metal complexes are presented. Therefore, porphyrins contain-

[a] Dr. J.-F. Longevial, Dr. S. Clément, Dr. S. Richeter Institut Charles Gerhardt, UMR 5253 CNRS-ENSCM-UM

Place Eugène Bataillon, CC1701, 34095 Montpellier (France)

E-mail: sebastien.richeter@umontpellier.fr

[b] Dr. J. A. Wytko, Dr. R. Ruppert, Dr. J. Weiss Institut de Chimie de Strasbourg UMR 7177 CNRS-Université de Strasbourg 4 rue Blaise Pascal, 67000 Strasbourg (France)

iD The ORCID identification number(s) for the author(s) of this article can be found under: https://doi.org/10.1002/chem.201801211.

i Selected by the Editorial Office for our Showcase of outstanding Reviewtype articles (www.chemeurj.org/showcase). ing, for example, appended crown ethers complexing alkali and alkaline earth metal ions are not included since they are discussed elsewhere. ${ }^{[7]}$ Here, we present selected examples of peripherally metalated porphyrins where the outer transition metal complexes can play key roles in catalysis, molecular electronics and biomedicine (Figure 1).

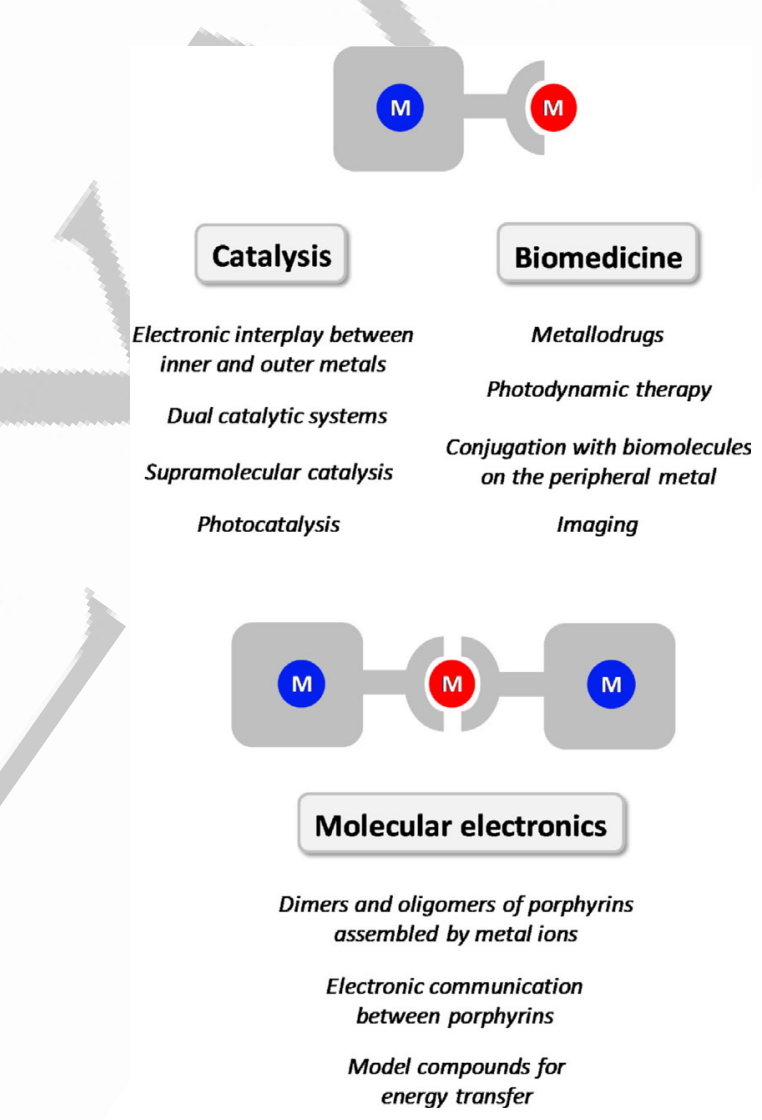

Figure 1. Topics discussed in this review.

\section{Catalysis with Peripherally Metalated Por- phyrins}

To explain enzymatic processes, iron porphyrins were actively investigated as mimics of cytochrome P-450 to understand the enzyme's catalytic activity. Besides these iron porphyrins, different metalloporphyrins catalyzed other reactions, including amination (with $\left.\mathrm{Co}^{[8]}\right)$, cyclopropanation $\left(\mathrm{Rh}^{\left[{ }^{[9]}\right.} \mathrm{Co}^{[10]}{ }^{\left[\mathrm{r}^{[11]}\right.}\right.$ ) or olefination $\left(\mathrm{Fe}^{[12]}\right)$ reactions. In this context, the use of peripherally metalated porphyrins for catalysis is a relatively recent field of research (less than two decades old). ${ }^{[13]}$ In this case, the periph- 
eral transition metal complexes play the role of catalytic sites, whereas the neighboring porphyrin can act: (i) as a modulating unit to tune the electronic and catalytic properties of the peripheral catalytic sites, (ii) as a secondary coordination site for supramolecular or dual catalysis, or (iii) as a light harvesting unit for dual photoredox and transition metal catalysis. These aspects are discussed hereafter.

\subsection{Modulation of the electronic and catalytic properties}

It was expected that the electronic and catalytic properties of the peripheral metal catalyst(s) could be modulated by the porphyrin due to possible electronic interplay between the outer and inner metal ions. Mizoroki-Heck coupling reactions between aryl halides and alkenes were extensively used by several research groups as "benchmark reactions" to evaluate the catalytic properties of porphyrins with peripheral Pd" complexes. In their pioneering work, Klein, Gebbink and co-workers

Please provide a biography (300-450 characters) and photo for: Jean-François Longevia Lorem ipsum dolor sit amet, consectetur adipiscing elit, sed do eiusmod tempor incididunt ut labore et dolore magna aliqua. Ut enim ad minim veniam, quis nostrud exercitation ullamco laboris nisi ut aliquip ex ea commodo consequat. Duis aute irure dolor in reprehenderit in voluptate velit esse cillum dolore eu fugiat nulla pariatur. Excepteur sint occaecat cupidatat non proident, sunt in culpa qui officia deserunt mollit anim id est laborum.

Please provide a biography (300-450 characters) and photo for: Sébastien Clément Lorem ipsum dolor sit amet, consectetur adipiscing elit, sed do eiusmod tempor incididunt ut labore et dolore magna aliqua. Ut enim ad minim veniam, quis nostrud exercitation ullamco laboris nisi ut aliquip ex ea commodo consequat. Duis aute irure dolor in reprehenderit in voluptate velit esse cillum dolore eu fugiat nulla pariatur. Excepteur sint occaecat cupidatat non proident, sunt in culpa qui officia deserunt mollit anim id est laborum.

Please provide a biography (300-450 characters) and photo for: Jennifer A. Wytko Lorem ipsum dolor sit amet, consectetur adipiscing elit, sed do eiusmod tempor incididunt ut labore et dolore magna aliqua. Ut enim ad minim veniam, quis nostrud exercitation ullamco laboris nisi ut aliquip ex ea commodo consequat. Duis aute irure dolor in reprehenderit in voluptate velit esse cillum dolore eu fugiat nulla pariatur. Excepteur sint occaecat cupidatat non proident, sunt in culpa qui officia deserunt mollit anim id est laborum.
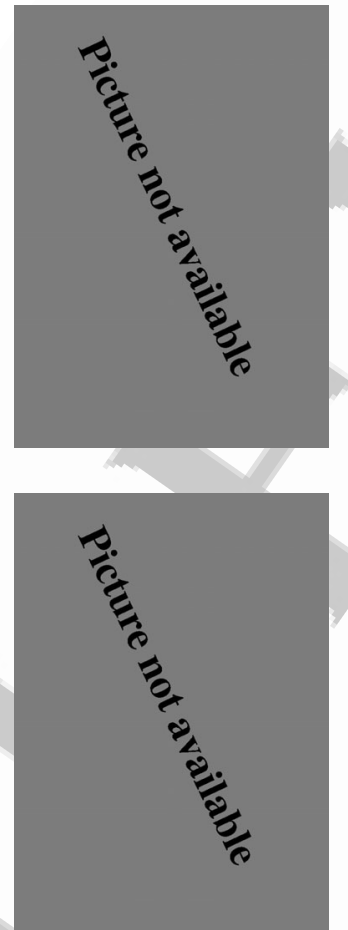

Please provide a biography (300-450 characters) and photo for: Jean Weiss Lorem ipsum dolor sit amet, consectetur adipiscing elit, sed do eiusmod tempor incididunt ut labore et dolore magna aliqua. Ut enim ad minim veniam, quis nostrud exercitation ullamco laboris nisi ut aliquip ex ea commodo consequat. Duis aute irure dolor in reprehenderit in voluptate velit esse cillum dolore eu fugiat nulla pariatur. Excepteur sint occaecat cupidatat non proident, sunt in culpa qui officia deserunt mollit anim id est laborum.

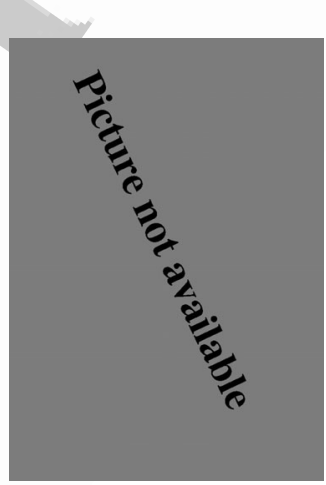

Please provide a biography (300-450 characters) and photo for: Romain Ruppert Lorem ipsum dolor sit amet, consectetur adipiscing elit, sed do eiusmod tempor incididunt ut labore et dolore magna aliqua. Ut enim ad minim veniam, quis nostrud exercitation ullamco laboris nisi ut aliquip ex ea commodo consequat. Duis aute irure dolor in reprehenvoluptate velit esse cillum dolore eu fugiat nulla pariatur. Excepteur sint occaecat cupidatat non proident, sunt in culpa qui officia deserunt mollit anim id est laborum.

Please provide a biography (300-450 charac ters) and photo for: Sébastien Richeter Lorem ipsum dolor sit amet, consectetur adipiscing elit, sed do eiusmod tempor incididunt ut labore et dolore magna aliqua. Ut enim ad minim veniam, quis nostrud exercitation ullamco laboris nisi ut aliquip ex ea commodo consequat. Duis aute irure dolor in reprehenderit in voluptate velit esse cillum dolore eu fugiat nulla pariatur. Excepteur sint occaecat cupidatat non proident, sunt in culpa qui officia deserunt mollit anim id est laborum. reported the synthesis of a series of symmetrical (metallo)porphyrins with four meso aryl groups bearing pincer-type ligands with NCN, SCS or PCP donor atoms and the corresponding Pd" complexes. ${ }^{[14]}$ The SCS-Pd" complexes 1-M ( $\mathrm{M}=\mathrm{Mg}^{\text {"I }}, \mathrm{Ni}^{\prime \prime}, \mathrm{Mn}^{\mathrm{III}} \mathrm{C}$ ere tested as pre-catalysts in the Mizoroki-Heck reac, and increased in the order $1-\mathrm{Mn}^{\prime \prime} \mathrm{Cl}<\mathbf{1 - 2} \mathrm{H}<1$ These catalytic activities are in line with the relative electrondonating abilities of the porphyrins. Control experiments confirmed that the differences in catalytic activities arose from in-
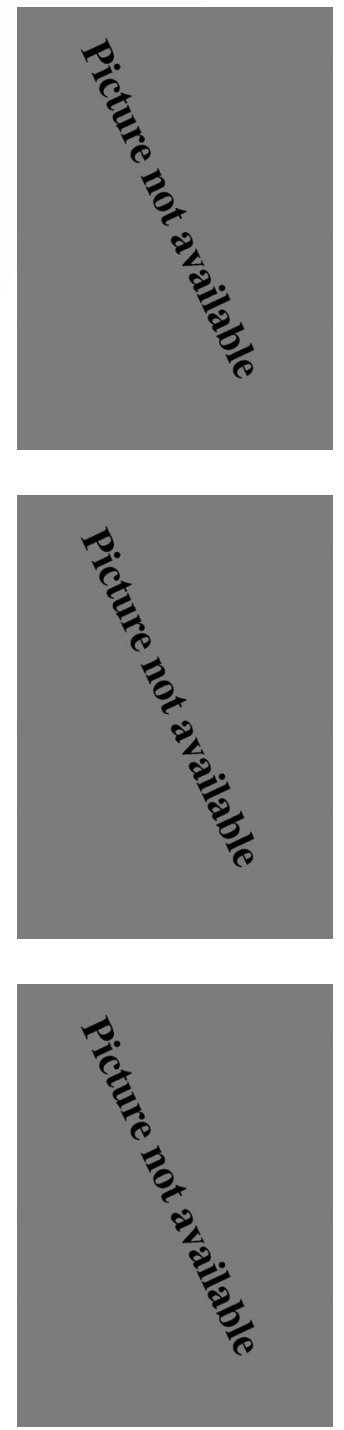

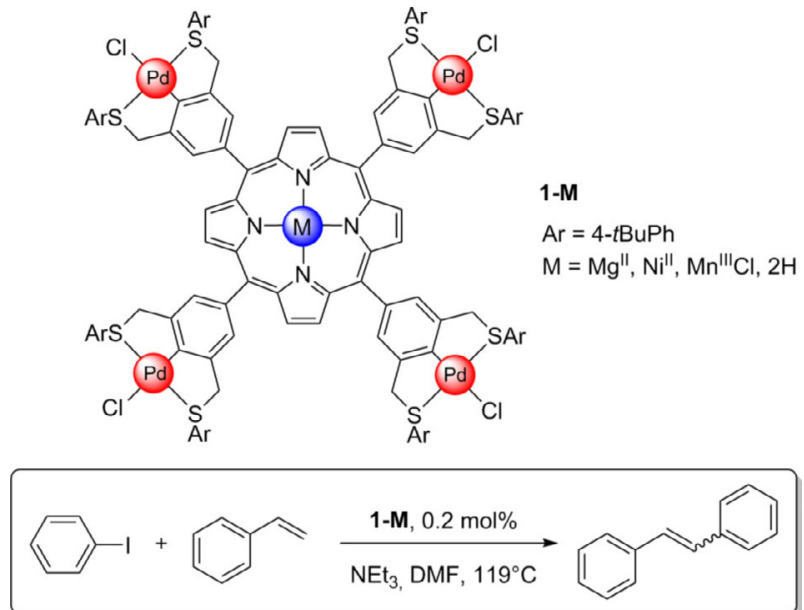

Scheme 1. Mizoroki-Heck reaction catalyzed by Pd complexes 1-M.

metal ion in the porphyrin directly influenced the electron-donating ability of the porphyrin and, hence, facilitated (or not) the leaching of $\mathrm{Pd}$ in the reaction mixture.

Stronger electronic interactions between the porphyrin and peripheral metal complexes are expected in the absence of orthogonal meso aryl groups. For example, the meso triarylporphyrin containing two pyridyl groups at the $\beta$-pyrrolic positions adjacent to the free meso carbon (see Scheme 2$)^{[16]}$ pro-
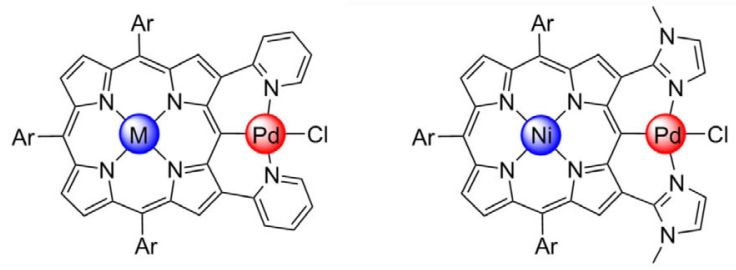

2-M

$\mathrm{Ar}=3,5-\mathrm{BBu}_{2} \mathrm{Ph}$

$\mathrm{M}=\mathrm{Zn}$ ", $\mathrm{Ni}^{\prime \prime}, \mathrm{Cu}^{\prime \prime}, 2 \mathrm{H}$

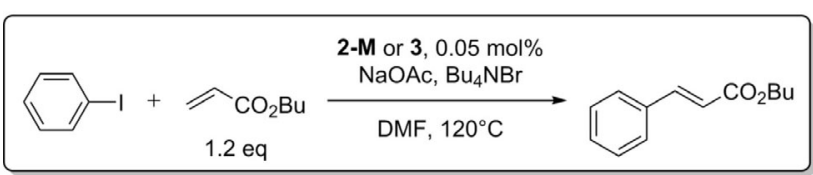

Scheme 2. Mizoroki-Heck reaction catalyzed by $\mathrm{Pd}$ complexes $\mathbf{2}-\mathbf{M}$ and $\mathbf{3}$.

vides an NCN pincer-type ligand was used for the synthesis of the corresponding $\mathrm{Pd}^{\prime \prime}$ complexes 2-M ( $\mathrm{M}=\mathrm{Zn}$ ", $\mathrm{Ni}^{\prime \prime}, \mathrm{Cu}^{\prime \prime}$ and $2 \mathrm{H})$. When these complexes were used as pre-catalysts in the Mizoroki-Heck reaction between iodobenzene and butyl acrylate, the catalytic activity strongly depended on the nature of the inner metal ion and increased in the order $\mathbf{2}-\mathbf{2} \mathbf{H}<\mathbf{2}-\mathbf{C u}$ " $<$ $\mathbf{2}-\mathbf{N i} \mathbf{i n}^{\prime \prime} \mathbf{2}-\mathbf{Z n}$ ". This observation was not discussed at that time but it was clear that the inner metal ion had a strong impact on the catalytic activity. Interestingly, when pyridyl ligands were replaced by $\mathrm{N}$-methyl imidazole, the apparent catalytic activity of complex $\mathbf{3}$ in the same reaction was enhanced compared to that of $2-\mathrm{Ni}^{\mathrm{il}}{ }^{[17]}$ This enhancement showed that a fine-tuning of the catalytic properties was achieved by modu- lating the nature of the ligands at the $\beta$-pyrrolic positions (Scheme 2). The same pincer ligand with pyridyl groups was used for the synthesis of the Ir' complex 4, which was catalytically active towards the hydrosilylation of ethyl cinnamate (Scheme 3). ${ }^{[18]}$
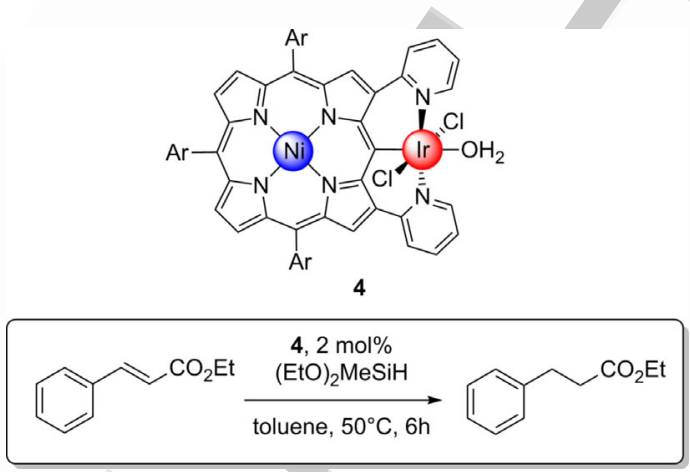

Scheme 3. Hydrosilylation reaction catalyzed by Ir complex 4 .

A porphyrin conjugated with a phenanthroline ligand was used in the synthesis of Pd" complexes 5-M (Scheme 4, M= $\mathrm{Zn}^{\prime \prime}, \mathrm{Ni}^{\prime \prime}, \mathrm{Cu}^{\prime \prime}, \mathrm{Mg}$ " and $\left.\mathrm{Co}^{\prime \prime}\right){ }^{[19]}$ These complexes were used as pre-catalysts for the Mizoroki-Heck reaction between iodobenzene and butyl acrylate. Similarly, to the results previously described, the observed catalytic activity was found to significantly depend on the inner metal ion. The complex $\mathbf{5}-\mathbf{Z n}$ " appeared to be the most active catalyst with a $100 \%$ conversion reached after 30 minutes. All other complexes were less active and $\mathbf{5}-\mathrm{Co}^{\prime \prime}$ was the least active.
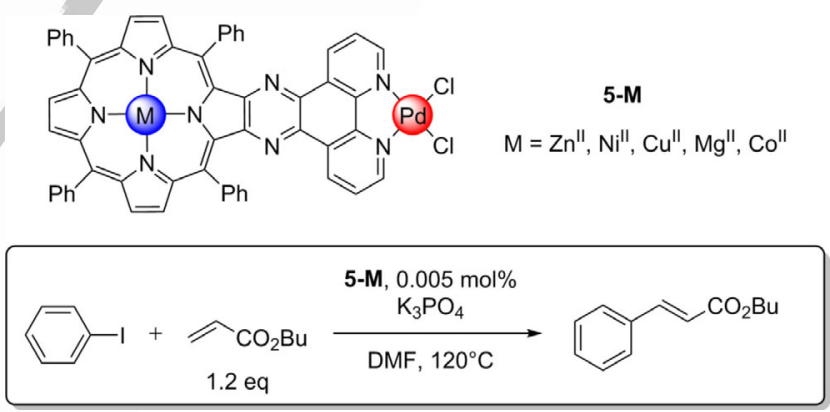

Scheme 4. Mizoroki-Heck reaction catalyzed by Pd complexes 5-M.

A $\mathrm{Zn}^{\prime \prime}$ meso triarylporphyrin, where the fourth meso position was functionalized with a diphenylphosphanyl group ${ }^{[20]}$ was used to prepare a $\mathrm{Zn}$ " bis( $\mu$-chloro)-bridged porphyrin appended phospha-palladacycle 6-Zn", which was further converted to the free-base- and Ni-porphyrin analogs $6-2 \mathrm{H}$ and 6-Ni". These complexes were tested as pre-catalysts in the MizorokiHeck reaction between $p$-bromobenzaldehyde and butyl acrylate (Scheme 5). The observed catalytic activity significantly depended on the metal in the porphyrin and increased in the order $\mathbf{6 - 2} \mathbf{H}<\mathbf{6 - Z n "}<\mathbf{6 - N i " . ~ H o w e v e r , ~ t h i s ~ o r d e r ~ d o e s ~ n o t ~ c o i n - ~}$ cide with the electron-donating ability of the porphyrin $\pi$ system, estimated from the first oxidation potentials. However, 

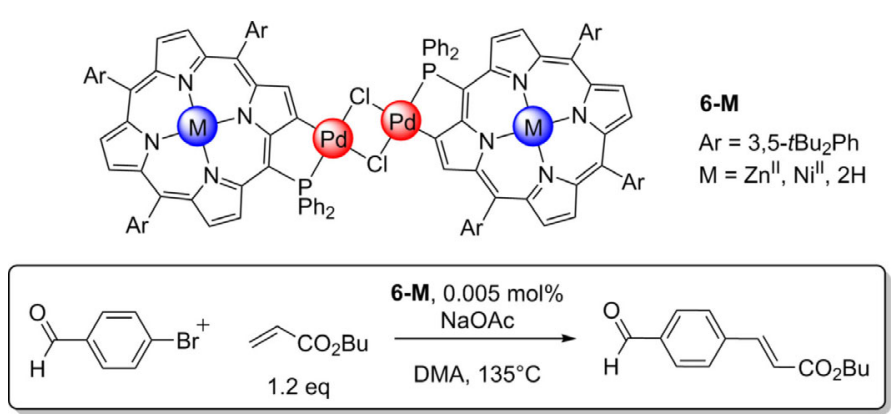

Scheme 5. Mizoroki-Heck reaction catalyzed by Pd complexes 6-M.

this order did correlate with the $\sigma$-donating ability of the phosphorus atom (estimated by ${ }^{31} \mathrm{P}$ NMR spectroscopy), which increases in the order: $\mathbf{6 - N i "}<\mathbf{6 - 2 H}<6-\mathrm{Zn}^{\prime \prime}$. Comparisons with the previously described Mizoroki-Heck reactions are difficult because aryl halides and catalyst loadings were different.

Since palladacycles readily decompose during MizorokiHeck reactions (see the previous examples), other types of peripheral ligands were studied. $\mathrm{N}$-heterocyclic carbenes (NHCs) are known to form very stable bonds with transition metal ions in low and high oxidation states and thus are actively used in organometallic chemistry and catalysis. Porphyrins fused to imidazolium salts $7-\mathbf{M}^{[21]}$ serve as NHC precursors for the synthesis of bis( $\mu$-iodo)-bridged Pd" complexes 8-M ( $M=$ $\mathrm{Ni}^{\prime \prime}, \mathrm{Cu}^{\prime \prime}, \mathrm{Zn}$ and $\left.2 \mathrm{H}\right){ }^{[22]}$ These complexes were tested as precatalysts in the Mizoroki-Heck reaction between iodobenzene and styrene (Scheme 6) and the observed catalytic activity depended on the absence or presence of a metal ion in the porphyrin. A conversion between $80-90 \%$ of iodobenzene was observed with compounds 8-M ( $\mathrm{M}=\mathrm{Ni}^{\prime \prime}, \mathrm{Cu}^{\prime \prime}$ and $\left.\mathrm{Zn}{ }^{\prime \prime}\right)$, whereas only $30 \%$ was observed with the free-base porphyrin $\mathbf{8 - 2 H}$ after 10 hours. Pd leaching occurred during the reaction and it was shown that leached Pd could be trapped by the inner coordination site of the porphyrin, thus decreasing the concen-

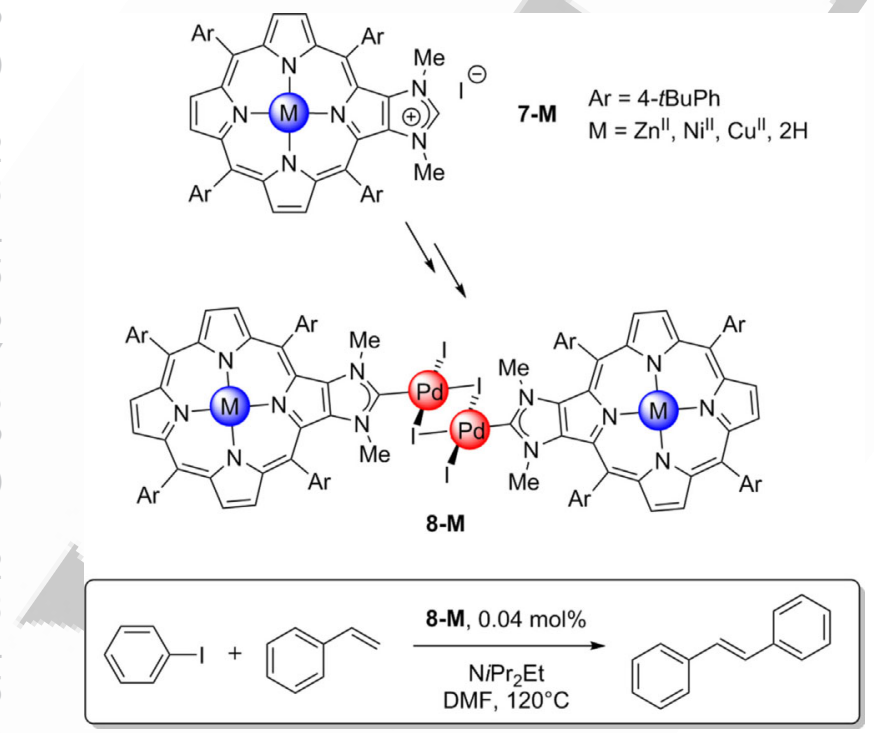

Scheme 6. Mizoroki-Heck reaction catalyzed by Pd complexes 8-M. tration of free Pd particles available for the coupling reaction. Interestingly, in almost all Mizoroki-Heck reactions presented so far in this section, the pre-catalysts incorporating free-base porphyrins are among the least active ones. Of course, steric and electronic properties are important, but other factors (axial coordination, solubility, etc.) should also be taken into account, including the possible trapping of $\mathrm{Pd}$ in the porphyrin macrocycle.

Many experimental observations made in the course of these investigations suggest that $\mathrm{Pd}^{\prime \prime}$ complexes decompose and release $\mathrm{Pd}^{0}$ colloids at elevated temperature, including when NHC-Pd" complexes are used as pre-catalysts. ${ }^{[23]}$ The Mizoroki-Heck reaction was probably not the best choice to demonstrate the electronic interplay between the inner metal in the porphyrin and the peripheral catalytic site. Therefore, other reactions and catalysts were investigated. In the course of their studies, Richeter and co-workers synthesized the $\mathrm{Rh}^{\prime}$ complexes 9-M ( $\mathrm{M}=\mathrm{Ni}^{\prime \prime}, \mathrm{Zn}$ ", $\mathrm{Mn}{ }^{\prime \prime \prime} \mathrm{Cl}, \mathrm{Al}{ }^{\prime \prime \prime} \mathrm{Cl}, 2 \mathrm{H}$ and $4 \mathrm{H}^{2+}$, see Scheme 7). ${ }^{[24]}$ The electron donating abilities of the peripheral

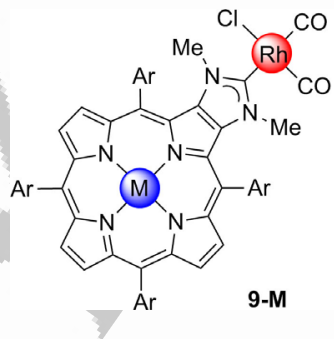

$\begin{array}{lc}\text { M } & v(\mathbf{C O}) \mathrm{cm}^{-1} \\ \mathrm{Zn}^{\prime \prime} & 2080,2001 \\ 2 \mathrm{H} & 2080,2002 \\ \mathrm{Ni} & 2081,2002 \\ \mathrm{Mn}^{\text {III }} \mathrm{Cl} & 2083,2003 \\ \mathrm{Al}^{\text {III }} \mathrm{Cl} & 2084,2004 \\ 4 \mathrm{H}^{2+} & 2089,2010\end{array}$

Scheme 7. Structures of $\mathrm{Rh}^{\prime}$ complexes 9-M. and $v(\mathrm{CO})$ values measured by IR spectroscopy.

$\mathrm{NHCs}$ were evaluated from the stretching vibrations of the $\mathrm{CO}$ ligand on $\mathrm{Rh}^{\prime}$ complexes 9-M. The $\sigma$-donating ability of the $\mathrm{NHCs}$ increased in the order $\mathrm{M}=4 \mathrm{H}^{2+}<\mathrm{A}^{\text {"II }} \mathrm{Cl} \approx \mathrm{Mn}{ }^{\prime \prime \prime} \mathrm{Cl}<\mathrm{Ni}$ " $\approx 2 \mathrm{H} \approx \mathrm{Zn}^{11} .{ }^{[24,25]} \mathrm{IR}$ spectroscopy was not sensitive enough to distinguish between 9-Zn", 9-Ni" and 9-2 H. However, the very small differences observed are in good agreement with the $\pi$ donating ability of the porphyrins, estimated from the first oxidation potentials of imidazolium salts 7-M. These potentials are shifted anodically in the order $\mathbf{7 - Z n ^ { \prime \prime }}(+0.36 \mathrm{~V})<\mathbf{7 - 2 H}$ (+ $0.57 \mathrm{~V})<7-\mathrm{Ni}^{\prime \prime}(+0.64 \mathrm{~V})$. Imidazolium salts 7-M ( $\mathrm{M}=\mathrm{Ni}^{\prime \prime}, \mathrm{Zn}^{\prime \prime}$, $\mathrm{Mn}{ }^{\mathrm{II}} \mathrm{Cl}, 2 \mathrm{H}$; see Scheme 6) were used as NHC precursors to catalyze the ring-opening polymerization (ROP) of L-lactide (L-LA) (Scheme 8$)^{[24]}$ The observed catalytic activity strongly depended on the metal ion inside the porphyrin and increased in the

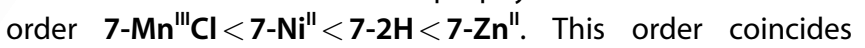
with the $\sigma$-donating ability of the NHCs as well as the $\pi$-donating ability of the porphyrins; the more electron-rich the porphyrin, the more catalytically active the peripheral NHC is towards the ROP of L-LA.

A phosphorus-containing PCP pincer-type ligand and the corresponding $\mathrm{Pd}^{\prime \prime} 10-\mathrm{M}$ and $\mathrm{Pt}^{\prime \prime}$ 11-M complexes ( $\mathrm{M}=\mathrm{Ni}^{\prime \prime}, \mathrm{Zn}$ and $2 \mathrm{H})^{[26]}$ were tested in the allylation reaction of benzaldehyde with allyltributyltin, because this reaction is known to proceed without significant decomposition of the catalyst (Scheme 9). However, the obtained data showed similar cata- 

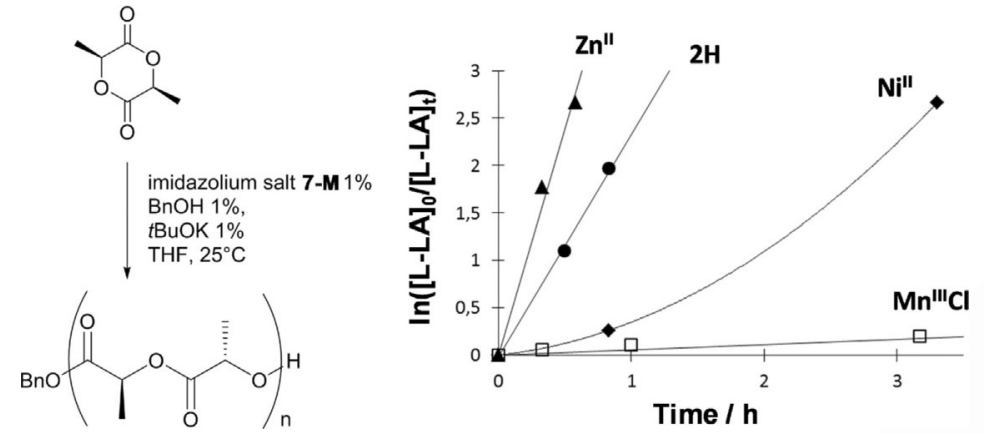

Scheme 8. Polymerization of L-LA catalyzed by porphyrin-NHCs generated in situ by deprotonating imidazolium salts 7-M. Plots of $\ln \left([\mathrm{L}-\mathrm{LA}]_{0} /[\mathrm{L}-\mathrm{LA}]_{\mathrm{t}}\right)$ versus time for $[\mathrm{L}-\mathrm{LA}]_{0}=2 \mathrm{M}$ and a targeted degree of polymerization of 100 .

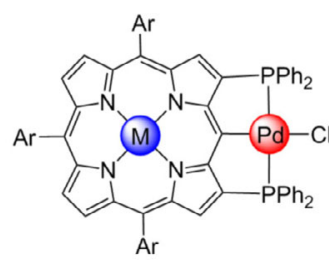

10-M $\mathrm{Ar}=3,5-\mathrm{BBu}{ }_{2} \mathrm{Ph}$ 10-M $\mathrm{M}=\mathrm{Zn}^{\|}, \mathrm{Ni}^{\|}, 2 \mathrm{H}$

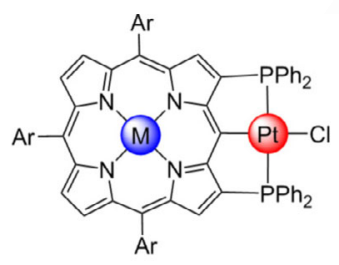

11-M $\mathrm{Ar}=3,5-\mathrm{BBu} \mathrm{B}_{2} \mathrm{Ph}$

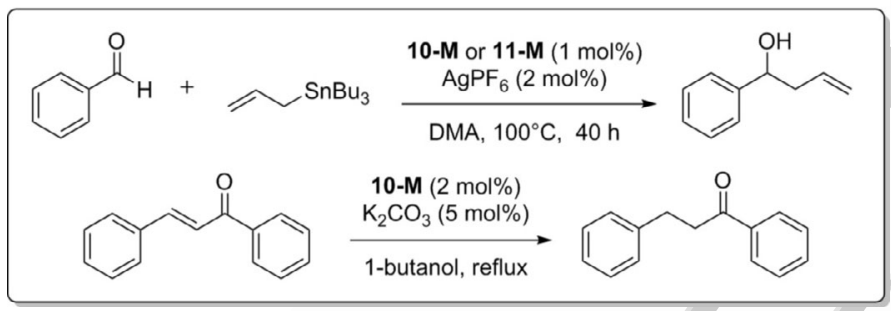

Scheme 9. Allylation reaction of benzaldehyde with allyltributyltin and 1,4reduction of chalcone through transfer hydrogenation catalyzed by Pd" complexes 10-M and $\mathrm{Pt}^{\prime \prime}$ complexes 11-M.

lytic activity for all catalysts, implying that the inner metal had little or no influence on the peripheral catalytic sites. The Pd" complexes 10-M ( $\mathrm{M}=\mathrm{Zn}^{\prime \prime}, \mathrm{Ni}^{\mathrm{il}}$ and $\left.2 \mathrm{H}\right)$ were also tested for the 1,4-reduction of chalcone through transfer hydrogenation (Scheme 9). In this case, the catalytic activity depended on the nature on the inner metal and increased in the order $10-2 \mathrm{H} \leq$ 10-Ni" $<\mathbf{1 0 - Z n " . ~ T h e ~ h i g h e r ~ a c t i v i t y ~ o b s e r v e d ~ f o r ~} \mathbf{1 0 - Z n " ~ i s ~ i n ~}$ agreement with its lower oxidation potentials compared to those of $\mathbf{1 0 - \mathrm { Ni } ^ { \prime \prime }}$ and $\mathbf{1 0 - 2} \mathrm{H}$, that is, the $\mathrm{Zn}$ " porphyrin is more electron-rich than the other two. It is important to note here that mercury poisoning tests excluded the formation of $\mathrm{Pd}$ nanoparticles in the course of the reaction.

\subsection{Dual catalytic systems and supramolecular assemblies}

As seen above, the modulation of the electronic properties of the aromatic core by the nature of the metal ion inside the porphyrin can have significant impact on the electronic and/or catalytic properties of peripheral metal complexes. However, the central metal ion can also be used as a secondary catalytic site for dual catalysis. Cationic Pd" complexes 12-M (M=Mg",
$\mathrm{Ni}^{\prime \prime}, \mathrm{Zn}$ and $2 \mathrm{H}$; Scheme 10) constructed from porphyrins bearing an NCN pincer-type ligand were tested as catalysts in the double Michael addition of ethyl- $\alpha$-cyanoacetate with methyl vinyl ketone. ${ }^{[27]}$ The observed catalytic activity did not depend of the porphyrin when $\mathrm{M}=\mathrm{Zn}$ ", $\mathrm{Ni}^{\text {il }}$ or $2 \mathrm{H}$ and was similar to the activity of the corresponding non-porphyrin complex. Interestingly, the catalytic activity increased by a factor of six when $\mathrm{M}=\mathrm{Mg}$ ". Control experiments suggest that simultaneous activation of methyl vinyl ketone by coordination of the carbonyl group to the Lewis acidic $\mathrm{Mg}^{\prime \prime}$ site and activation of ethyl- $\alpha$-cyanoacetate bound to the cationic Pd" complex within supramolecular assemblies may explain the enhanced activity. Interestingly, combining Mg"TTP and cationic [Pd(NCN)OH $\mathrm{OH}_{2} \mathrm{BF}_{4}$ into one molecule 12-Mg" led to a three-fold increase of its catalytic activity compared to that found for a 1:1 mixture of its constituents. Indeed, the Mg" porphyrin and the peripheral Pd" complex act in a cooperative way when they are connected together.

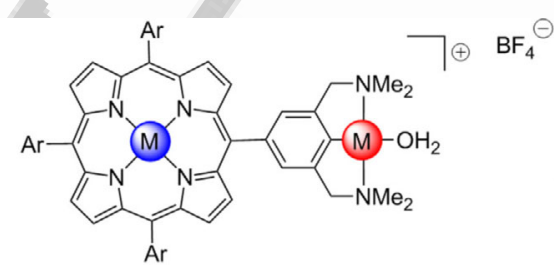

12-M

$\mathrm{Ar}=4-\mathrm{MePh}$ $\mathrm{M}=\mathrm{Zn}^{\prime \prime}, \mathrm{Ni}^{\prime \prime}, \mathrm{Mg}^{\prime \prime}, 2 \mathrm{H}$

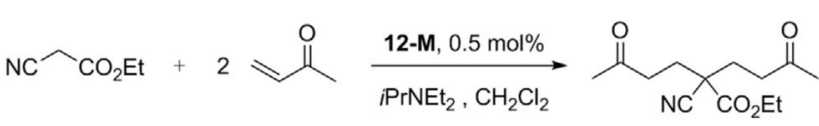

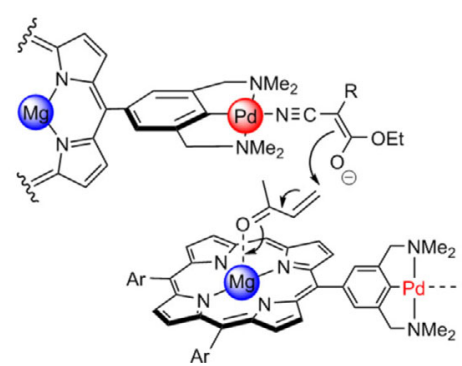

Scheme 10. Double Michael addition of ethyl- $\alpha$-cyanoacetate with methyl vinyl ketone catalyzed by complexes 12-M. Below: possible mechanism to explain the increased catalytic activity when $\mathbf{M}=\mathbf{M g}$ ".

Other reported examples of such "cooperative dual catalytic systems" include the synthesis of phenanthroline-strapped porphyrin [2]rotaxanes by a copper-catalyzed alkyne-azide cycloaddition. ${ }^{[28]}$ The cooperative and simultaneous activation of both the azide, by the $\mathrm{Zn}$ " porphyrin of 13, and of the alkyne, by the phenanthroline-bound $\mathrm{Cu}^{\prime}$, dramatically improved the yield of rotaxanes (Scheme 11).

Metalloporphyrins are also attractive molecules in the field of supramolecular chemistry. Well-defined finite species can be obtained by self-assembly via axial coordination to metal ions such as $\mathrm{Zn}^{\prime \prime}$ in the porphyrins. In catalysis, this supramolecular 

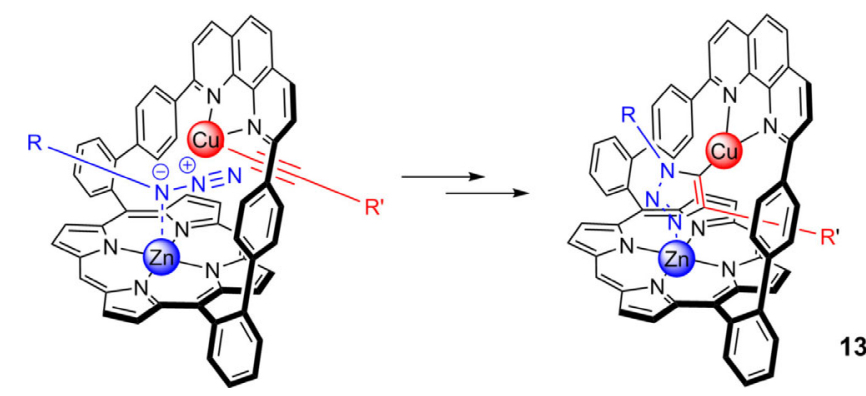

Scheme 11. Synthesis of phenanthroline-strapped porphyrin [2]rotaxane 13 through a Cu-catalyzed alkyne-azide cycloaddition reaction.

approach was applied to construct bidendate ligands by combining two phosphorus-based ligands, one with a pyridyl ligand as donor and another appended to a $\mathrm{Zn}$ " porphyrin (Scheme 12). ${ }^{[29]}$ The self-assembled Supraphos ligand 14 was tials in their excited states and their ground states close to those of $\left[\mathrm{Ru}(\mathrm{bpy})_{3}\right]^{2+}{ }^{[32]}$ can be used for photocatalytic applications such as reduction of $\mathrm{CO}_{2}$ to $\mathrm{CO}$ or $\mathrm{H}_{2}$ evolution.

Converting $\mathrm{CO}_{2}$ into valuable chemicals is of interest especially if solar energy is employed. Towards this goal, a series of $\mathrm{Re}^{\prime}$ complexes 15-M ( $\mathrm{M}=\mathrm{Cu}^{\prime \prime}, \mathrm{Pd}^{\prime \prime}, \mathrm{Zn}^{\prime \prime}, \mathrm{Co}$ " and $\left.\mathrm{Fe}{ }^{\prime \prime \prime} \mathrm{Cl}\right)$ based on a porphyrin conjugated with a phenanthroline ligand. ${ }^{[33]}$ were tested as catalysts for the photochemical reduction of $\mathrm{CO}_{2}$ to $\mathrm{CO}$ in DMF using triethylamine as a sacrificial electron donor (Scheme 13). For these heterodinuclear complexes, the active catalytic center is the peripheral $\operatorname{Re}^{\prime}$ complex and not the (metallo)porphyrin. The nature of the metal center in the porphyrin, as well as the irradiation conditions, strongly influences the reduction of $\mathrm{CO}_{2}$ to $\mathrm{CO}$. The $\mathrm{Re}^{\prime}$ complex conjugated with the $\mathbf{Z n}$ " porphyrin $\mathbf{1 5 - Z n}$ is the most active photocatalyst with a turnover number $\left(\mathrm{TON}_{\mathrm{CO}}\right)$ of 13 after 24 hours of irradiation at $\lambda>375 \mathrm{~nm}$. All other photocatalysts show minimal activity under these conditions. Investigation of the photoreduction of $\mathrm{CO}_{2}$ by three types of $\mathrm{Zn}^{\prime \prime}$ porphyrin-Rel dyads 16,17 and 18 showed that the TON ${ }_{C O}$ obtained with 18 was 360 after 7 hours of irradiation at $\lambda>520 \mathrm{~nm}$ (Scheme 13). ${ }^{[34]}$ This value is one order of magnitude higher than those of $\mathbf{1 6}$ and 17. It was also noticed that the $Z n^{\prime \prime}$ porphyrins were reduced to $\mathrm{Zn}^{\prime \prime}$ chlorins (and $\mathrm{Zn}$ " isobacteriochlorins), which are also active sensitizers. Complete bleaching renders the dyads inactive. Interestingly, the use of a saturated bridge between the porphyrin and the $\mathrm{Re}^{\prime}$ complexes was beneficial and in accord with results obtained for Ru-Re complexes. ${ }^{[35]}$

Scheme 12. Schematic representation of a $\mathrm{Rh}^{\prime}$ complex with Supraphos ligand $\mathbf{1 4}$ for the Rh-catalyzed hydroformylation of styrene.

successfully used for the challenging Rh-catalyzed, hydrogenation of enamide substrates, the Pd-catalyzed kinetic resolution of racemic cyclohexenyl acetate, and the Rh-catalyzed hydroformylation of styrene. The powerful aspect of this supramolecular approach is that a vast library of 48 bidendate ligands was obtained from only six porphyrin derivatives and eight monodentate phosphorus ligands.

\subsection{Photocatalysis}

Generally, Ru and Ir complexes are at the forefront of photoredox catalysis because of their high redox potentials in the excited states. ${ }^{[30]}$ Visible light is used to perform photoinduced electron transfer with substrates through oxidative/reductive quenching pathways. Combining a photosensitizer with a second metal catalyst leads to dual catalytic systems with novel reactivity that is sometimes not accessible using either of the compounds independently. ${ }^{[31]}$ Most of the time, the two components are not linked together (bimolecular systems). Dual catalytic systems where the two components are connected, that is, in close proximity (unimolecular systems), and able to act in a cooperative way are less common. Some challenging reactions could surprisingly be achieved or enhanced with such systems under visible light irradiation ("photo-assisted" catalysis). Porphyrin derivatives, which have redox poten-
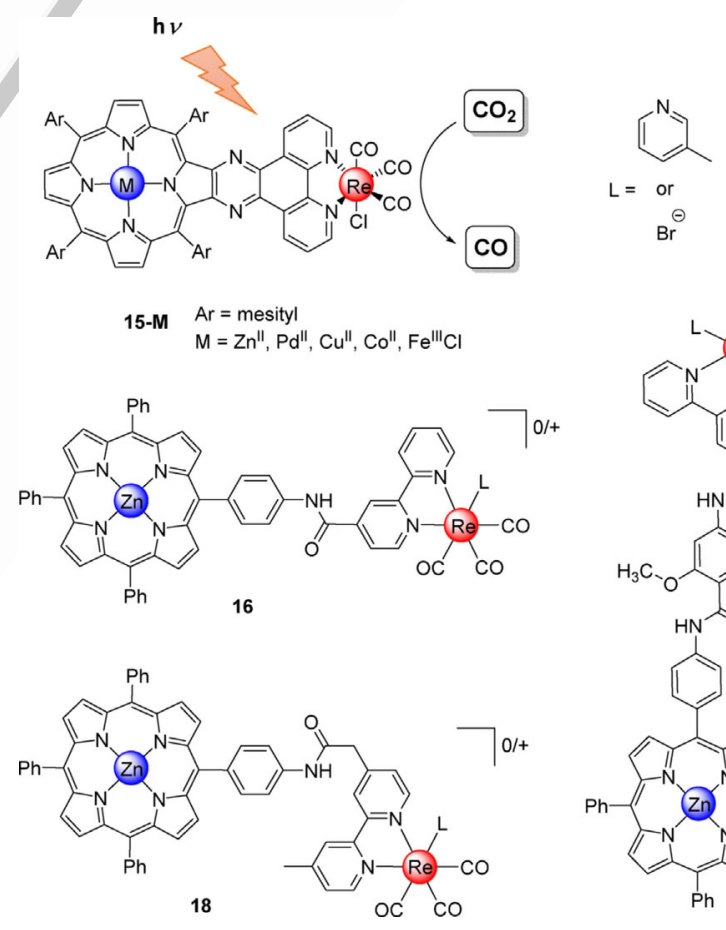

the photoreduction of $\mathrm{CO}_{2}$ to $\mathrm{CO}$. 
Photochemical production of $\mathrm{H}_{2}$ with noble-metal-free molecular species is still a hot topic for the development of future cost-effective, environmentally benign sources of energy. Complexes belonging to the class of cobaloximes are active catalysts for the photoinduced generation of $\mathrm{H}_{2}$. Sun and co-workers reported the synthesis of porphyrins 19-M ( $\mathrm{M}=\mathrm{Zn}$ ", $\mathrm{Mg}^{\prime \prime}$ and $2 \mathrm{H}$ ) with one meso 4-pyridyl group that acts as an apical ligand for the complex $\left[\mathrm{Co}^{\text {III }}(\mathrm{dmgH})_{2}(\mathrm{Cl})\right]^{ \pm 0}(\mathrm{dmg}=$ dimethylglyoxime, Scheme 14). ${ }^{[36]}$ Photoinduced $(\lambda>400 \mathrm{~nm}) \mathrm{H}_{2}$ gener-
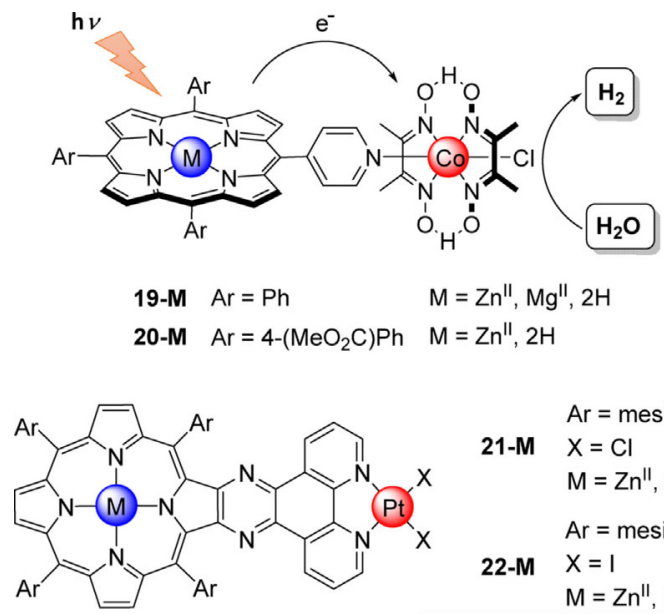

$$
\begin{array}{ll}
\text { 21-M } & \begin{array}{l}
\text { Ar }=\text { mesityl } \\
X=C l
\end{array} \\
& M=Z n^{\prime \prime}, C u^{\prime \prime}, C o^{\prime} \\
& A r=\text { mesityl } \\
\text { 22-M } & X=I \\
& M=Z n^{\prime \prime}, C u^{\prime \prime}, C o^{\prime \prime}
\end{array}
$$

Scheme 14. Structures of porphyrin cobaloxime complexes 19-M and 20-M, and $\mathrm{Pt}^{\mathrm{II}}$ complexes 21-M and 22-M for photoinduced $\mathrm{H}_{2}$ generation.

ation, in a $\mathrm{THF}-\mathrm{H}_{2} \mathrm{O}$ solution containing $\mathrm{NEt}_{3}$, with $19-\mathrm{M}$ as photocatalysts, strongly depends on the inner metal of the porphyrin. A TON $\mathrm{H}_{2}$ of 22 was observed after 5 hours with 19-

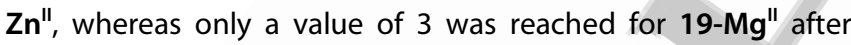
3 hours. Only trace amounts of $\mathrm{H}_{2}$ were detected for $19-2 \mathrm{H}$ under these conditions. Guldi, Coutsolelos, Gryko and co-workers investigated photophysical and catalytic properties of similar dyads 20-M $(\mathrm{M}=\mathrm{Zn}$ and $2 \mathrm{H})$ and discussed the possible photochemical processes leading to the formation of catalytically active species (Scheme 14). ${ }^{[37]}$ Again, the photocatalyst 20-Zn" was the most efficient for $\mathrm{H}_{2}$ evolution. In other photocatalytic studies with $\mathrm{Pt}^{\prime \prime}$ complexes 21-M and 22-M ${ }^{[38]}$ based on a porphyrin conjugated with a phenanthroline ligand, the catalytic evolution of $\mathrm{H}_{2}$ depended on the nature of $M$ in the inner core of the porphyrin and the halides bound to the Pt"

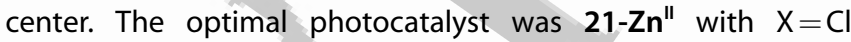
$\left(\mathrm{TON}_{48 \mathrm{~h}}=25\right.$ and 2, respectively for $21-\mathbf{Z n}^{\prime \prime}$ and $22-\mathbf{Z n}^{\prime \prime} ; \lambda=$ $470 \mathrm{~nm}$ in $\mathrm{CH}_{3} \mathrm{CN} /$ trimethylamine/ $\mathrm{H}_{2} \mathrm{O}$ 6:3:1).

\section{Molecular Electronics with Porphyrins As- sembled by Transition Metal lons}

Mimicking the properties of natural systems with synthetic porphyrin derivatives has been the subject of intense research during the last few decades. Porphyrin dimers and oligomers assembled by covalent or non-covalent bonds have been investigated to better understand the electronic interactions between the chromophores in their ground and excited states. In this section, some representative examples of porphyrin dimers and oligomers assembled by transition metal ions are presented along with the factors important for efficient electronic communication between the porphyrins.

\subsection{Factors governing electronic interactions between por- phyrins in the ground state}

An early example of a porphyrin dimer assembled by a transition metal was reported by Lehn and Drain (Scheme 15). ${ }^{[39]}$ In dimer 23, meso 4-pyridyl units are used as peripheral ligands and square-planar Pd" ions with a trans geometry are used as

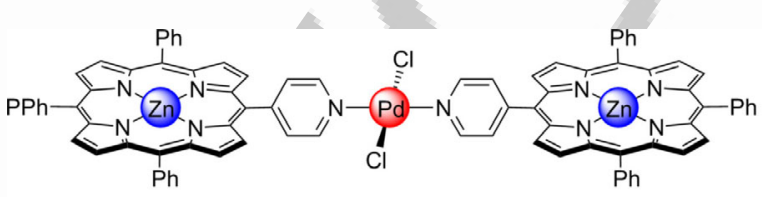

23

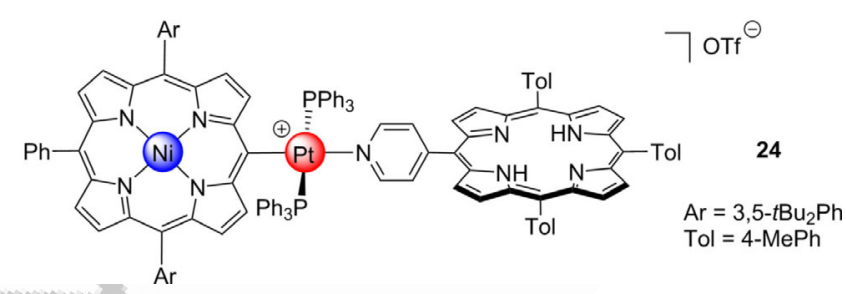

Scheme 15. Structures of dimeric species 23 and 24.

assembling metals. The electronic interactions between the porphyrins through the assembling metal were evaluated in the ground state by UV-visible spectroscopy. Soret absorption bands of such porphyrin dimers are moderately red-shifted (6$8 \mathrm{~nm}$ ) and extinction coefficients per porphyrin ( $\approx 80 \%)$ are substantially lower than that of the parent porphyrin. These observations suggest that electronic communication between the porphyrins is quite weak. The lack of interactions between the porphyrins of dimer $\mathbf{2 3}$ can be attributed to the fact that the meso pyridyl ligands are nearly orthogonal to the porphyrin planes. Although porphyrin-porphyrin interactions are weak, this is an extremely powerful approach to build complex multiporphyrinic architectures. ${ }^{[40]}$ Porphyrin dimer 24 and other oligomers with similar pyridyl bridging units (Scheme 15) ${ }^{[41]}$ contain a platinum ion directly linked to the porphyrin core. Despite the direct $\sigma$-bond between one porphyrin and the $\mathrm{Pt}^{\mathrm{Il}}$ complex, only weak electronic interactions were observed between the porphyrins (Soret bands are red-shifted by $\approx 1$ $5 \mathrm{~nm}$ when inner $\left.\mathrm{M}=\mathrm{Ni}^{\mathrm{il}}\right)$. As stated by the authors, the bridging metal fragment "acts more as a structural component than a conjugative linking group" in this case.

With this in mind, porphyrins with coplanar and conjugated peripheral coordination sites were expected to display larger electronic interactions between the porphyrins within dimeric structures. However, this is not always the case, as seen for trans-[Pd"I $\left.\mathrm{I}_{2}(\mathrm{NHC})_{2}\right]$ complexes 25-M in which two porphyrinNHC ligands are coordinated to Pd" (Scheme 16). ${ }^{[42]}$ Clearly, the UV-visible spectra of the dimeric structures 25-M correspond to the sum of the spectra of the individual porphyrins, and the 


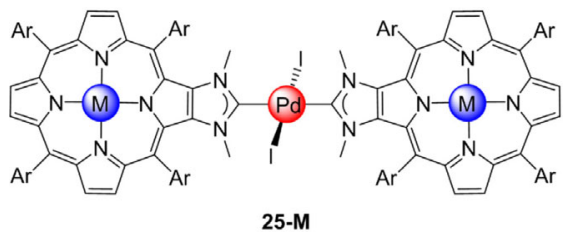

25-M

$\mathrm{M}=\mathrm{Ni}$ ", $\mathrm{Zn}$ ", $\mathrm{Cu}^{\prime \prime}, 2 \mathrm{H}$

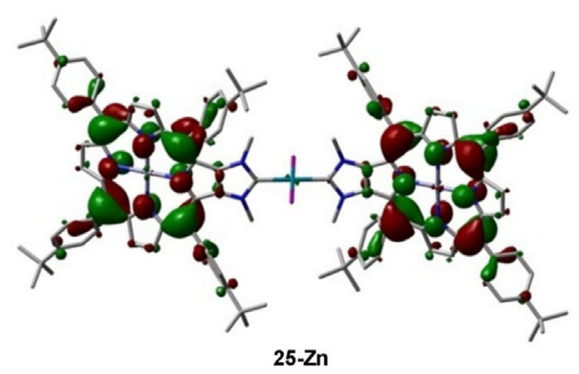

HOMO $-5.03 \mathrm{eV}$

Scheme 16. Structures of Pd" complexes 25-M and representation of the HOMO orbital of the $\mathbf{2 5 - Z n}$ complex calculated by DFT.

cyclic voltammograms (CVs) of complexes 25-M are similar to the sum of the CVs of the individual porphyrins. These data suggest that there is no electronic communication between the porphyrins despite the conjugation between the porphyrin core and the NHC ligands. DFT calculations corroborated the experimental findings: no significant atomic contribution of the coordination unit ( $\mathrm{Pd}^{\prime \prime}$ and carbene) was found in the frontier orbitals, thus preventing orbital overlap between the porphyrins through the assembling metal. ${ }^{[43]}$

In previous systems 23-25 porphyrin cores, peripheral ligands and/or assembling metal ( $\mathrm{Pd}^{\prime \prime}$ or $\mathrm{Pt}$ ") are not coplanar. The planarity of the entire assembly can be enforced by introducing peripheral chelating sites conjugated with the porphyrin $\pi$-system. Porphyrins conjugated with an enaminoketone $\mathbf{2 6 - M}$ were used to construct fully planar dimeric species where the porphyrins are assembled by square-planar metal ions such as $\mathrm{Pd}^{\text {"I }}$ or Pt" (Scheme 17). ${ }^{[4]}$ In these dimers, 27-M

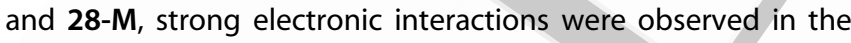
ground state between the porphyrins. ${ }^{[45]}$

The UV-visible spectra of the dimers 27-M do not correspond to the sum of the UV-visible spectra of the individual

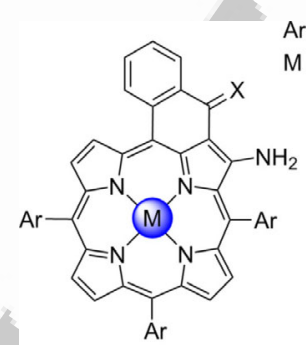

26-M $X=0$

29-M $\quad X=S$

$$
\mathrm{Ar}=3,5-t \mathrm{Bu}_{2} \mathrm{Ph}
$$
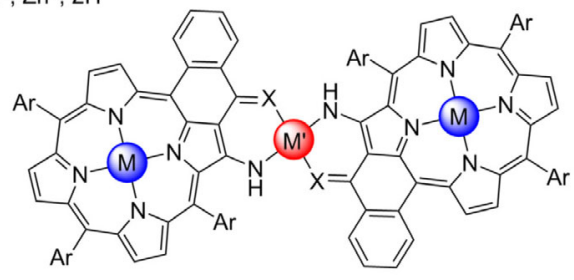

30-M $X=S ; M^{\prime}=P d$

28-M $X=O ; M^{\prime}=P t$ 31-M $X=S ; M^{\prime}=P t$

$$
\mathrm{M}=\mathrm{Ni}{ }^{\prime \prime}, \mathrm{Zn}^{\prime \prime}, 2 \mathrm{H}
$$

27-M $\quad X=O ; M^{\prime}=P d$

Scheme 17. Structure of porphyrins conjugated with enamino(thio)ketone 26-M and 29$\mathbf{M}$ and dimeric species with $\mathrm{Pd}^{\prime \prime}$ (27-M and 30-M), and Pt" (28-M and 31-M) as assembling metal ions. porphyrins 26-M. The intense Soret absorption bands are broad and split and the $\mathrm{Q}$ absorption bands $(500-700 \mathrm{~nm})$ are bathochromically shifted with respect to the monomeric porphyrins (See Figure $2 \mathrm{a}$ for UV-visible absorption spectra of monomer 26-Ni and dimer 27-Ni). The electronic communication between the porphyrins through the assembling metal was

a)
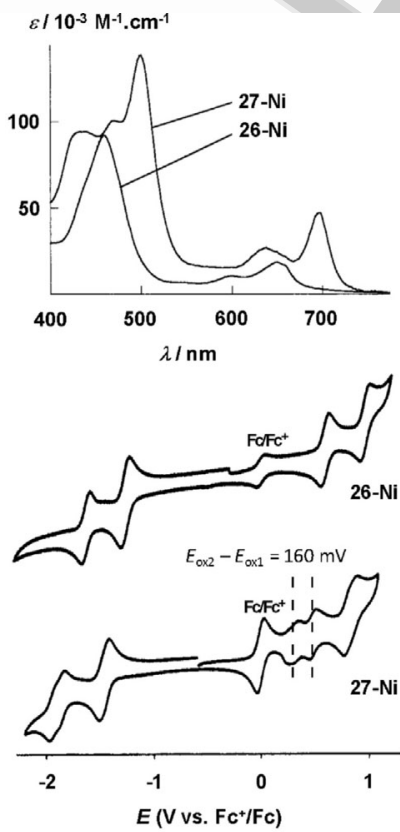

c)

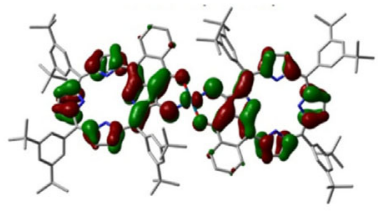

HOMO of $27-2 \mathrm{H}(-4.93 \mathrm{eV})$

Figure 2. a) UV-visible absorption spectra of 26-Ni and 27-Ni. b) Cyclic voltammograms of 26-Ni and 27-Ni. c) Representation of the HOMO of Pd" complex 27-2H calculated by DFT.

confirmed by electrochemical studies. For monomeric porphyrins 26-M, two monoelectronic reversible oxidation and two monoelectronic reversible reduction processes were observed by cyclic voltamperometry. The cyclic voltammograms of the dimeric species 27-M did not correspond to the sum of the electrochemical properties of individual porphyrins and some significant changes were observed. First, electrochemical gaps $\left(\Delta E=E_{\mathrm{ox} 1}-E_{\mathrm{red} 1}\right)$ decreased when going from monomers 26-M to dimers 27-M. Second, some redox potentials are split, notably the first oxidation waves, which are split into two welldefined one-electron processes with splitting values $\left(\Delta E=E_{\mathrm{ox} 2}-E_{\mathrm{ox} 1}\right)$ ranging from $120-180 \mathrm{mV}$ for

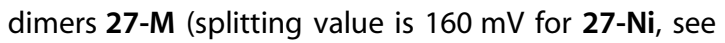
Figure $2 \mathrm{~b}$ ). This phenomenon is also observed in conjugated dimeric species where porphyrins are linked together by covalent organic spacers $(80 \mathrm{mV}$ and $260 \mathrm{mV}$ for a $\mathrm{C}=\mathrm{C}$ and $\mathrm{C}=\mathrm{C}$, respectively). ${ }^{[4,47]}$ The highest splitting value reported so far is $410 \mathrm{mV}$ 
for $\mathrm{C}_{\beta}-\mathrm{C}_{\text {meso }}-\mathrm{C}_{\beta}$ triply fused $\mathrm{Ni}^{\prime \prime}$ porphyrin dimers reported by Osuka and co-workers. ${ }^{[48]}$ The splitting of the first oxidation wave is due to the delocalization of the resulting radical cation over both porphyrins. This delocalization renders the oxidation of the second porphyrin more difficult. DFT calculations showed a significant atomic contribution of the $d$ orbitals of the linking metal to the frontier molecular orbitals, allowing electronic communication between the two porphyrins (Figure $2 \mathrm{c}$ ).

Interestingly, replacement of the oxygen atom of the chelating site by a sulfur atom was feasible with Lawesson's reagent (see structure of 29-M). ${ }^{[49,50]}$ This small change led to enhanced electronic interactions between the porphyrins in the

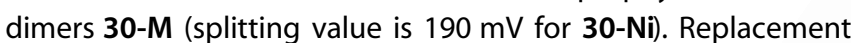
of $\mathrm{Pd}^{\text {" }}$ by $\mathrm{Pt}^{\mathrm{I}}$ also dramatically enhanced the electronic communication between the porphyrins in dimers 28-M and 31-M as demonstrated by splitting values of the first oxidation waves of 220 and $280-290 \mathrm{mV}$ for $\mathbf{2 8 - N i}$ and 31-Ni, respectively. Higher oligomers, such as trimers $\mathbf{3 2}$ and $\mathbf{3 3}$ linked by coordination bonds (Scheme 18) were constructed from porphyrins bearing two peripheral chelating sites. ${ }^{[51]}$ Again, electronic interactions between the individual porphyrins were observed. ${ }^{[52]}$

Meso triarylporphyrins in which the fourth meso position was unsubstituted and one of the two neighboring $\beta$-pyrrolic positions was functionalized with a pyridyl group were used as

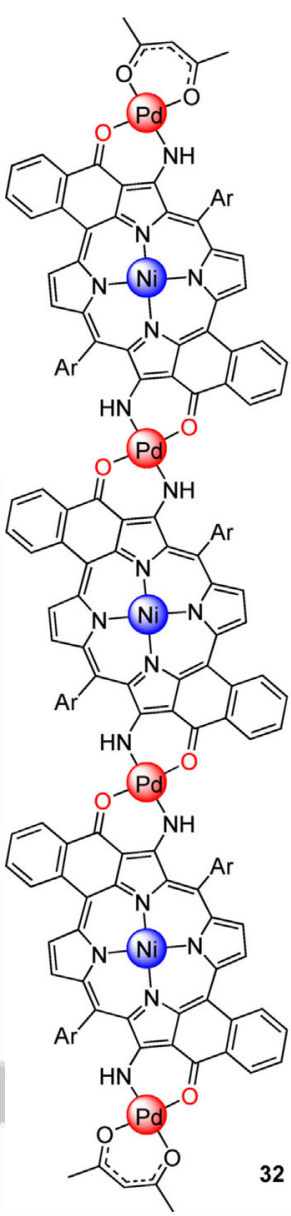

$\mathrm{Ar}=3,5-\mathrm{tBu} \mathrm{B}_{2} \mathrm{Ph}$

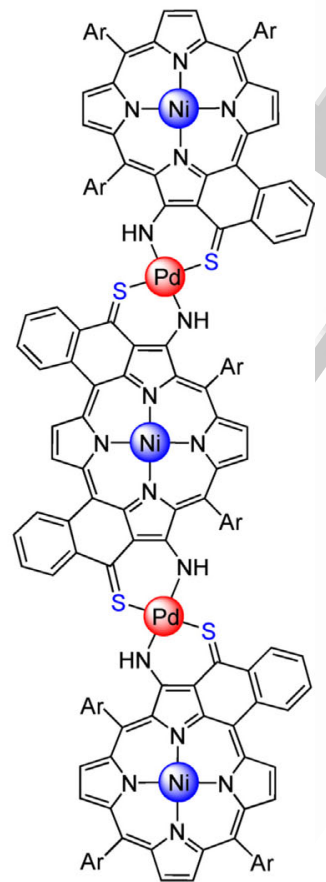

33

Scheme 18. Structures of trimers 32 and 33 building blocks for the synthesis of a cofacial dimer 34 with a $\mathrm{C}_{\text {meso }}-\mathrm{Pt}^{\mathrm{I}}-\mathrm{C}_{\text {meso }}$ linkage in a cis geometry (Scheme 19). ${ }^{[53]}$ The two porphyrins strongly interact through the cis $\mathrm{Pt}$ ", as shown by electrochemical studies. A splitting value of $230 \mathrm{mV}$ be-

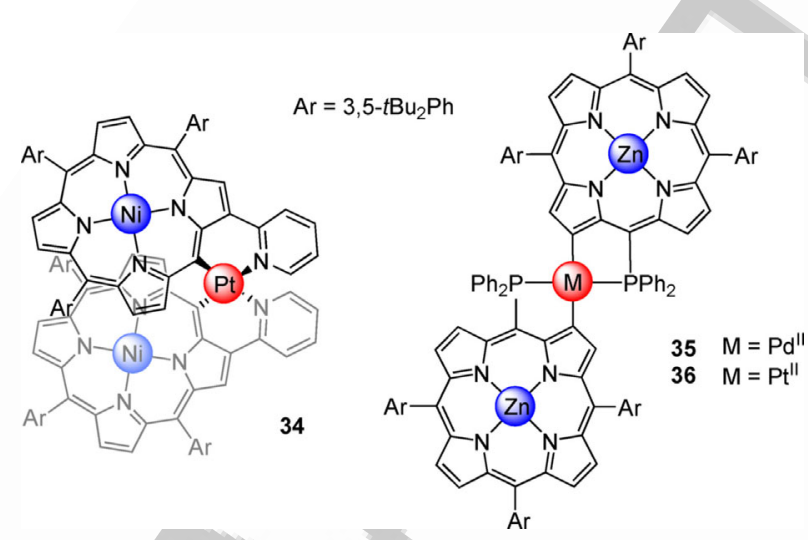

Scheme 19. Structures of dimeric species 34-36.

tween the first two one-electron oxidation waves was observed. Interestingly, this dimer shows helical chirality, which may be useful for asymmetric catalysis. In contract to $\mathbf{3 4}$, the electronic communication is quite weak in coplanar $\mathrm{C}_{\beta}$-to- $\mathrm{C}_{\beta}$ $\mathrm{Pd}^{\prime \prime}$ and $\mathrm{Pt}$ " porphyrin dimers $\mathbf{3 5}$ and $\mathbf{3 6}$ with a trans geometry (Scheme 19). ${ }^{[54]}$ A meso diphenylphosphanyl group was used to construct these coplanar dimers with $C_{\beta}-M-C_{\beta}$ linkages $(M=$ $\mathrm{Pd}^{\prime \prime}$ or $\left.\mathrm{Pt}^{\prime \prime}\right)$. Electrochemical studies revealed small splitting values, ranging from $40 \mathrm{mV}$ ( $\mathrm{Pd}^{\prime \prime}$ in 35) to $60 \mathrm{mV}$ ( $\mathrm{Pt}^{\prime \prime}$ in 36), between the first two one-electron oxidation waves. A similar splitting value of $60 \mathrm{mV}$ was reported for a series of butadiyneand $\mathrm{Pt}$ " diacetylide-bridged conjugated porphyrin dimers. ${ }^{[55]}$

In $\mathrm{C}_{\text {meso }}$-to- $\mathrm{C}_{\text {meso }} \mathrm{Pt}$ "-bridged porphyrin dimers $\mathbf{3 7}$ and $\mathbf{3 8}$ with trans and cis geometry, respectively (Scheme 20), ${ }^{[56]}$ strong electronic communication between the two porphyrins was demonstrated by UV-visible spectroscopy and electrochemical
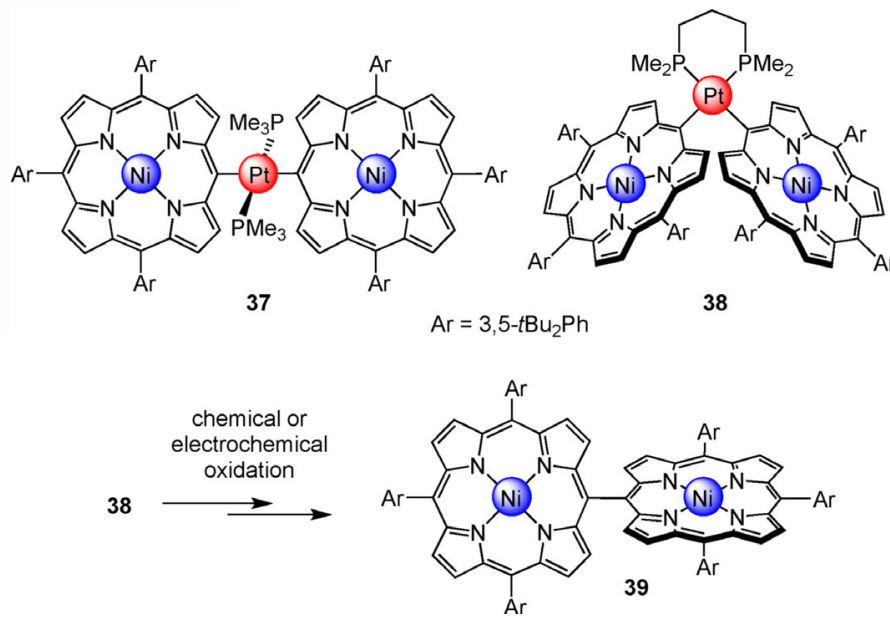

Scheme 20. Structures of trans-dimer $\mathbf{3 7}$ and cis-dimer 38. Structure of the meso-meso linked dimer $\mathbf{3 9}$ obtained after chemical or electrochemical oxidation of the cis-dimer 38. 
studies. For the trans-dimer $\mathbf{3 7}$, the splitting value of the first oxidation wave was $170 \mathrm{mV}$, which is in the range of values found for dimers 27-M. DFT calculations showed a clear contribution of the Pt" $d$ orbitals in the trans geometry to the frontier molecular orbitals. A through-bond conjugation between the porphyrins was postulated. For the cis-dimer 38, DFT calculations showed through-space interactions between the porphyrins in the frontier molecular orbitals, notably between the two carbon atoms linked to Pt". Interestingly, the electrochemical behavior of the cis-dimer $\mathbf{3 8}$ was very different because a chemical transformation occurred after the first oxidation, leading to the formation of the meso-meso linked dimer 39 through a surprising reductive elimination. This transformation could also be achieved by a chemical oxidation.

\subsection{Electronic interactions between the porphyr- ins in the excited state}

Natural porphyrin analogues such as chlorophylls and bacteriochlorophylls ensure energy and electron transfer processes in photosynthetic systems with high efficiencies and rates (as fast as 100-150 femtoseconds for some energy transfers) ${ }^{[57]}$ Several donoracceptor (D-A) systems with different geometries, orientations and distances between the chromophores were studied in order to better understand
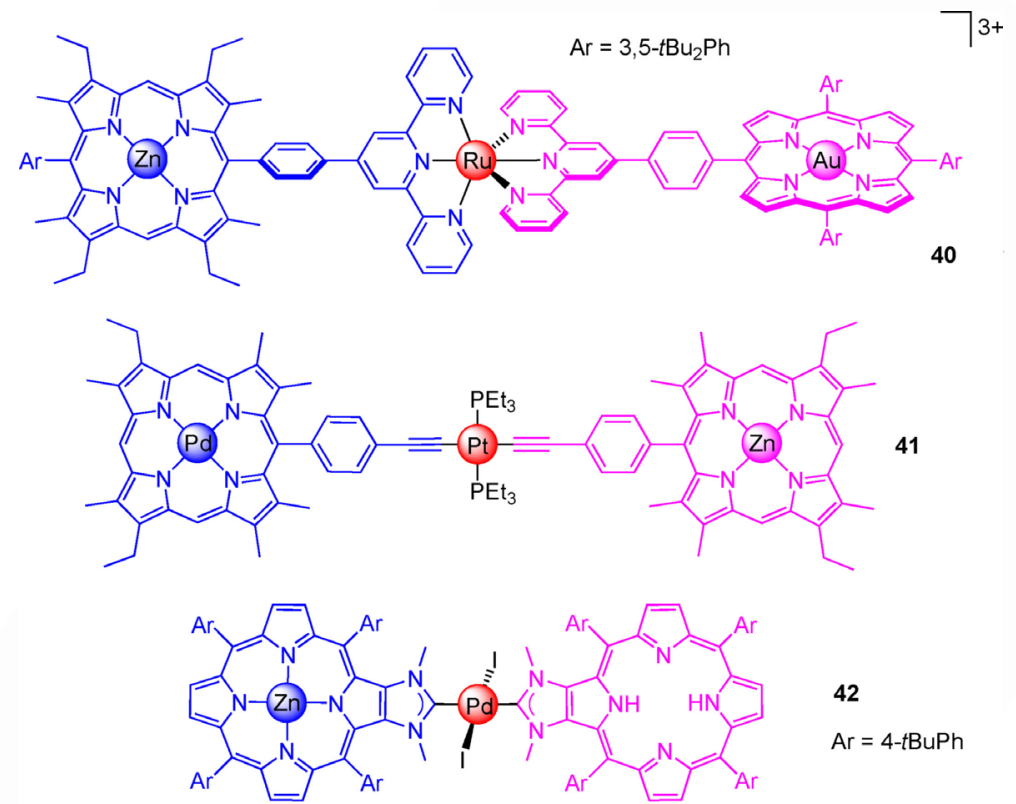
neering works by several authors including J.-P. Sauvage and co-workers studied electron transfers in bis-porphyrinic D-A systems like $\mathbf{4 0}$, where the individual units were connected by metal ions (Scheme 21). ${ }^{[58]}$ Later, other systems were built to study the faster energy transfer processes (see dyads 41-43 in Scheme 21). ${ }^{[4,59,60]}$ In this section are summarized some important results concerning $S_{1}$ energy transfer rates within molecular D-A systems, where D and A are assembled with metal complexes.

There are two possible processes of $S_{1}$ energy transfer between $D$ and $A$ within dyads, namely Förster and Dexter mechanisms (Figure 3). The Förster resonance energy transfer (FRET) mechanism is a "through space" coulombic energy transfer that necessitates a close proximity $(\approx 1-10 \mathrm{~nm})$ between $D$ and A (Figure $3 \mathrm{a}$ ). The Dexter mechanism is a "through bond" exchange energy transfer occurring only over short distances $(<1 \mathrm{~nm})$ between $D$ and $A$. As this mechanism corresponds to a double exchange of electrons between $D$ and $A$, molecular orbital overlap between them is essential (Figure $3 \mathrm{~b}$ ). As shown in the next paragraphs, the $S_{1}$ energy transfer rates between $D$ and $A$ within molecular D-A systems vary dramatically by modifying the nature of the peripheral ligands and the bridging transition metal ions.

Photophysical studies of the dyad 41, where a Pd" porphyrin (D) and a $\mathrm{Zn}$ " porphyrin (A) are linked together by an organo-

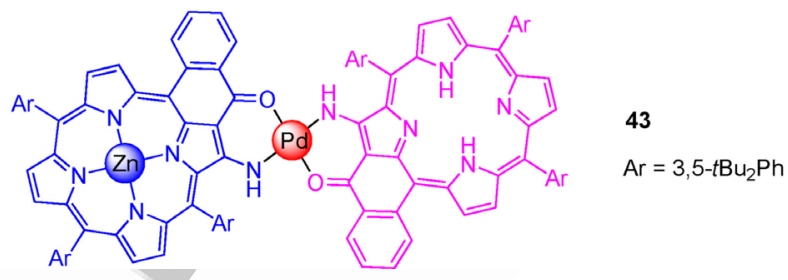

cheme $\mathbf{2 1}$. Structures of dyads $\mathbf{4 0 - 4 3}$ with donors in blue and acceptors in pink.
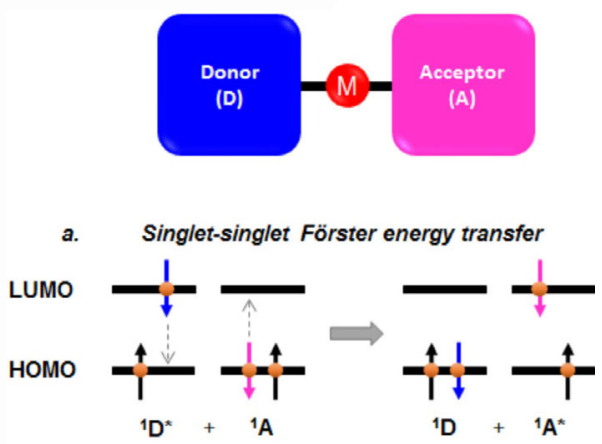

b. Singlet-singlet Dexter energy transfer

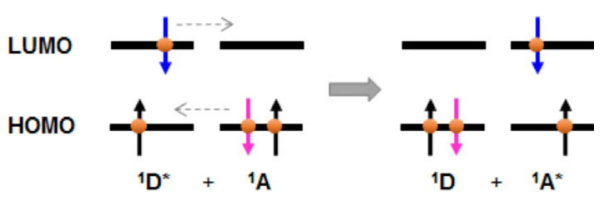

Figure 3. Schematic diagrams of Förster (a) and Dexter (b) energy transfer processes between a donor (D) and an acceptor (A).

metallic spacer (Scheme 21), ${ }^{[59]}$ showed that the energy transfer rates were quite slow $\left(S_{1}\right.$ energy transfer rate of $\left.\approx 500 \mathrm{ps}\right)$. Energy transfer rates were also slow $\left(S_{1}\right.$ energy transfer of $\approx 90-330 \mathrm{ps}$ ) in dyad 42 containing a $\mathrm{Zn}$ " porphyrin (D) and a free-base porphyrin (A) fused to peripheral NHC ligands and 
linked together by a trans $\mathrm{Pd}^{\prime \prime} \mathrm{I}_{2}$ complex. ${ }^{[43]}$ DFT calculations for 42 clearly showed the lack of Pd" atomic contributions to the $\pi$-system of the frontier molecular orbitals (Figure 4, left side). Therefore, the Dexter mechanism cannot operate and $\mathrm{S}_{1}$

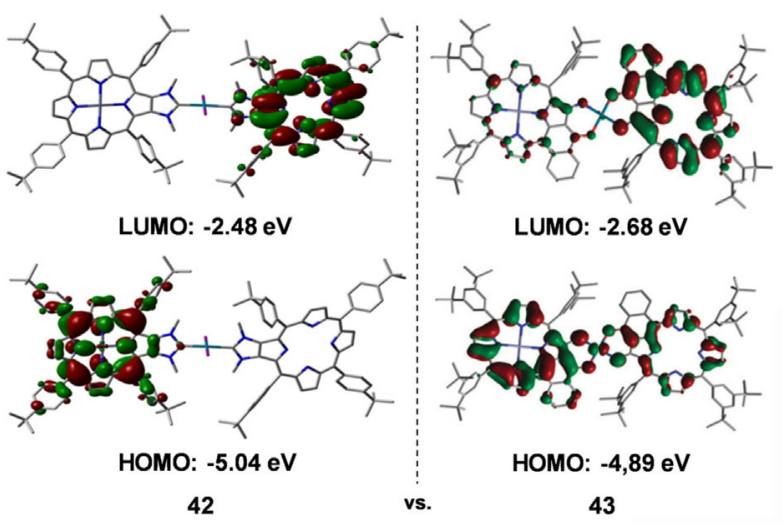

Figure 4. Representation of the frontier molecular orbitals HOMO and LUMO for dyads 42 and 43.

energy transfer is only due to Förster resonance energy transfer (FRET). However, the $S_{1}$ energy transfer rate is much slower than the predicted values when considering only FRET. This slow transfer may be explained by an electric field screening of the donor and the acceptor transition moments by the electron-rich trans $\mathrm{Pd}^{\prime \prime} \mathrm{I}_{2}$ complex, which slows down the energy transfer rate.

Energy transfer rates in the two previous dyads $\mathbf{4 1}$ and $\mathbf{4 2}$ suggest that the presence of a transition metal in the bridge between the porphyrins has a negative impact on the energy transfer rates between the porphyrins, but this is not always the case. For example, a $Z n$ " porphyrin (D) and a free-base porphyrin (A), each bearing an enaminoketone, were assembled around a square planar Pd" to give dyad $\mathbf{4 3}$ that exhibited a very fast $S_{1}$ energy transfer that takes place in $\approx 660 \mathrm{fs} .^{[60]}$ This value is comparable to the one found for covalently mesomeso linked bis-porphyrins $(\approx 550 \mathrm{fs}){ }^{[61]}$ This fast rate is due to a strong electronic communication between the porphyrin through the assembling Pd". DFT calculations show a significant atomic contribution of the $d$ orbital to the frontier molecular orbitals (MO) (4.6\% for the HOMO) allowing orbital overlap between the two porphyrins. Consequently, the Dexter mechanism operates efficiently (Figure 4, right side). Moreover, the absence of additional ligands on the square planar $\mathrm{Pd}^{\prime \prime}$ is probably beneficial since there is no electric field screening effect of ancillary ligands. Replacing Pd" by Pt" significantly decreases the time needed for the $S_{1}$ energy transfer, which is $\approx 105 \mathrm{fs}$ for the dyad 44 because $\mathrm{Pt}$ " allows stronger molecular orbitals coupling between the two porphyrins (Scheme 22). ${ }^{[62]}$ DFT calculations showed higher atomic contribution of the $\mathrm{Pt}^{\prime \prime}$ $d$ orbital to the frontier MO compared to Pd" $(11.2 \%$ for the $\mathrm{HOMO}$ ). The fastest $S_{1}$ energy transfer $(<50 \mathrm{fs})$ was reached in dyad $\mathbf{4 5}$ where oxygen atoms were replaced by sulfur atoms in the peripheral chelating sites. ${ }^{[50]}$ Again, DFT calculations showed higher atomic contribution of the $\mathrm{Pt}$ " $d$ orbital to the

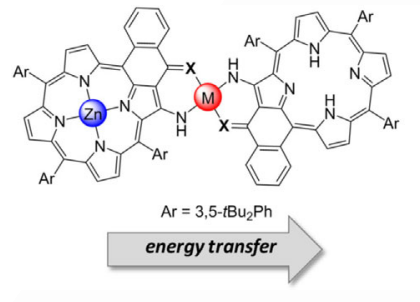

$\begin{array}{cccc} & \text { X } & \text { M } & \begin{array}{c}\text { time of } \\ \text { transfer }\end{array} \\ 43 & \mathrm{O} & \mathrm{Pd} & \sim 660 \mathrm{fs} \\ 44 & \mathrm{O} & \mathrm{Pt}^{\prime \prime} & \sim 105 \mathrm{fs} \\ 45 & \mathrm{~S} & \mathrm{Pt}^{\prime \prime} & <50 \mathrm{fs}\end{array}$

Scheme 22. $S_{1}$ energy transfer in dyads 43-45.

frontier MO (13.5\% for the HOMO) leading to increased molecular orbitals coupling between the porphyrins and better electronic communication.

In conclusion, the use of transition metal ions as linkers between a donor and an acceptor is feasible and dyads with ultrafast energy transfer rates can be obtained by judiciously choosing the ligands and the metal ion. One disadvantage of these systems compared to covalently linked dyads is that the heavy atom effect of the bridging metal favors the formation of the $T_{1}$ state by depleting the $S_{1}$ state (intersystem crossing, ISC). Nevertheless, this ISC is of great importance when considering other applications, such as photodynamic therapy, discussed in the next section.

\section{Photodynamic Therapy Applications}

In the field of biomedical applications, porphyrin derivatives are mainly used as photosensitizers (PS) for photodynamic therapy (PDT) applications. For effective PDT, light and molecular oxygen $\left({ }^{3} \mathrm{O}_{2}\right)$ are the two essential elements in addition to a PS. Ideally, the PS is first accumulated in cancer cells and then irradiated with light. As shown in the simplified Jablonski diagram in Figure 5, the PS absorbs light at a suitable wavelength (ideally in the photo-therapeutic window $650-900 \mathrm{~nm}$ for better depth penetration through tissues) to promote the $\mathrm{S}_{0} \rightarrow$ $\mathrm{S}_{1}$ excited state. Then, the singlet excited state $\mathrm{S}_{1}$ is converted to the lower energy excited triplet state $T_{1}$ through ISC. The PS in its $\mathrm{T}_{1}$ state can transfer its energy to ${ }^{3} \mathrm{O}_{2}$ to generate reactive singlet oxygen $\left({ }^{1} \mathrm{O}_{2}\right)$, which is a highly oxidizing and cytotoxic agent. PDT offers spatial and temporal control because the generated ${ }^{1} \mathrm{O}_{2}$ has lifetimes of $\approx 3 \mu$ s and limited diffusion coefficients of $\approx 2-4 \times 10^{-6} \mathrm{~cm}^{2} \mathrm{~s}^{-1}$ in biological media. ${ }^{[63,64]}$ In this section, representative examples of porphyrin-based PS periph-

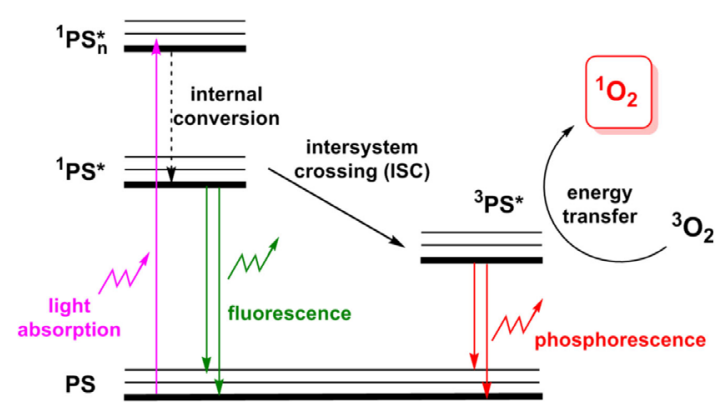

Figure 5. Simplified Jablonski diagram explaining the photophysical processes leading to the formation of ${ }^{1} \mathrm{O}_{2}$. 
erally metalated with transition metal ions are presented. The benefits obtained from these metal complexes for therapy and imaging applications will be emphasized.

\subsection{Porphyrins with peripheral platinum complexes}

Platinum complexes are powerful anticancer agents and one identified mode of action is their ability to crosslink purine bases of DNA. These stable complexes interfere with DNA repair machinery and ultimately lead to death of cancer cells. Cisplatin and carboplatin are active towards bladder, ovarian, head, neck, testicular and lung cancers. However, many side effects are associated with the use of these complexes. To improve their efficiency and limit the side effects, Pt complexes are combined with molecules known to preferentially accumulate in tumor tissues. Song and co-workers synthesized freebase porphyrins 46 with three meso 4-methylpyridinium groups that ensure water solubility (Scheme 23). ${ }^{[65]}$ The fourth meso position was functionalized with an aryl group bearing $\mathrm{Pt}^{\prime \prime}$ complexes. The anticancer properties of such Pt" porphyrin conjugates are superior to those of cisplatin due to a higher accumulation in tumors because of the porphyrin.

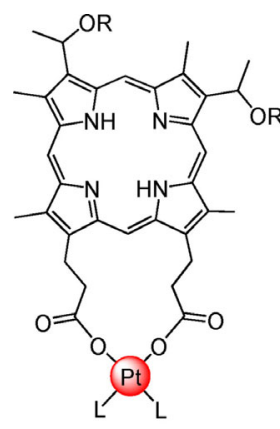

47

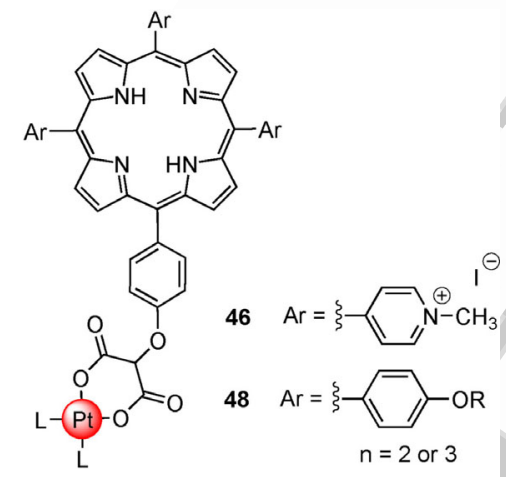

$\mathrm{R}=\left(\mathrm{CH}_{2} \mathrm{CH}_{2} \mathrm{O}\right)_{n} \mathrm{CH}_{3}$ $\mathrm{n}=2-5,12$ or $\sim 17$

$\mathrm{L}=\mathrm{NH}_{3}$ or $\mathrm{LL}=$ diamino ligands with red light. The light-induced toxicity is improved compared to their hematoporphyrin analogues when irradiated under the same conditions $\left(\lambda=600-730 \mathrm{~nm} ; 10 \mathrm{~min} ; 24 \mathrm{~J} \mathrm{~cm}^{-2}\right)$.

Tetraplatinated porphyrins 49 and 50 (Scheme 24), obtained by reacting the free-base meso-tetra(4-pyridyl)porphyrin with $\mathrm{Pt}^{\prime \prime}$ complexes, were used for photodynamic therapy applica-

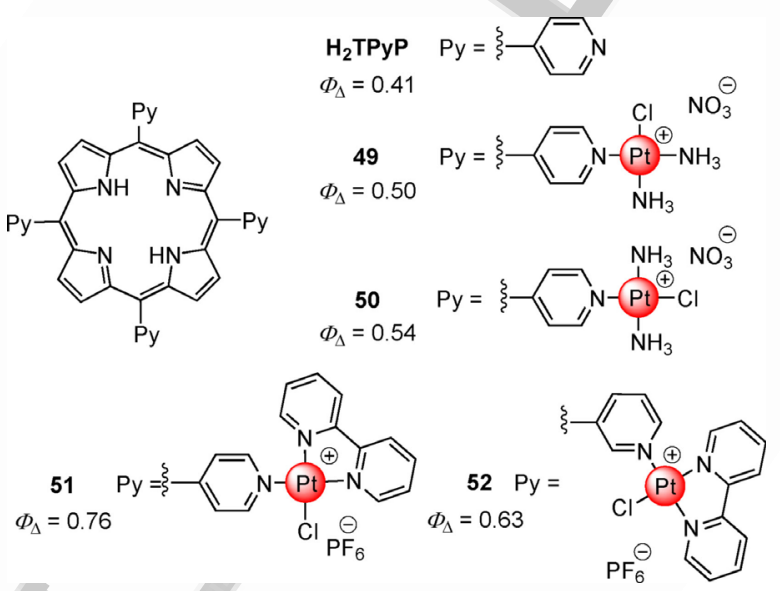

Scheme 24. Structures of $\mathrm{H}_{\mathbf{2}} \mathrm{TPyP}$ and $\mathrm{Pt}$ "-porphyrin conjugates 49-52. ${ }^{1} \mathrm{O}_{2}$ quantum yields $\Phi_{\Delta}$ indicated determined in DMF for $\mathrm{H}_{2}$ TPyP, 49 and 50 and in $\mathrm{CH}_{3} \mathrm{CN}$ for $\mathbf{5 1}$ and 52 .

tions. ${ }^{[68]}$ The ${ }^{1} \mathrm{O}_{2}$ quantum yields $\left(\Phi_{\Delta}\right)$ of $\mathbf{4 9}$ (cis geometry) and 50 (trans geometry) are higher than that of the corresponding non-platinated porphyrin, suggesting that the $\mathrm{Pt}$ " ions promote the formation of the $T_{1}$ state through a heavy atom effect. In vitro studies were performed on different cell lines. Interestingly, Pt"-porphyrin conjugates $\mathbf{4 9}$ and $\mathbf{5 0}$ show very limited toxicity on HeLa cells in the dark compared to cisplatin, but the toxicity upon irradiation (incubation time: 4 hours, irradiation conditions: $\lambda=420 \mathrm{~nm}, 15 \mathrm{mn}, 6.95 \mathrm{~J} \mathrm{~cm}^{-2}$ ) is $600-$ 1200 times higher. The factor corresponding to the phototoxic index $\left(\mathrm{PI}=\mathrm{IC} \mathrm{C}_{50}\right.$ in the dark/ $I \mathrm{C}_{50}$ irradiated) for PS $\mathbf{5 0}$ is $>5000$ in cisplatin-resistant cell line CP70 suggesting that dual chemo- and phototherapy is a very promising approach for cancer therapy. Subcellular colocalization studies showed improved accumulation of these PS in the nucleus (30 times more than cisplatin). This is a great advantage because DNA is the main identified biological target for Pt" complexes. Viscometry experiments, emission and absorption spectroscopy, circular dichroism studies and NMR spectroscopy showed that PS 50 can interact with DNA; although no damage of DNA was observed in the dark, significant cleavage and damage of the DNA occurred upon light irradiation.

The use of meso-3-pyridyl ligands instead of meso-4-pyridyl ligands has a significant impact on the PDT efficiency (Scheme 24). ${ }^{[69]}$ Both tetraplatinated porphyrins 51 and 52 have high singlet oxygen quantum yields, and are phototoxic at the nanomolar scale. However, PS $\mathbf{5 2}$ (3-pyridyl) is twice as phototoxic as 51 (4-pyridyl) despite a lower $\Phi_{\Delta}$. The overall better efficiency of PS $\mathbf{5 2}$ was attributed to its higher intracellular concentration compared to PS 51. The different charge distribution in $\mathbf{5 1}$ and $\mathbf{5 2}$ confers more amphiphilicity to $\mathbf{5 2}$ 
and thus better membrane affinity or permeability and cellular uptake. Therefore, the PS with the highest $\Phi_{\Delta}$ is not always the best PS for PDT. The number, the nature and the localization of the peripheral metal complexes are important factors to consider when designing a PS for dual chemo- and phototherapy. The observed benefits of these $\mathrm{Pt}^{\mathrm{I}}$ complexes are due to synergistic effects (the overall effect is greater than the sum of individual effects): the porphyrin macrocycle improves the cellular uptake of Pt" complexes possibly via low density lipoproteins (LDL) receptors over-expressed by cancer cells, whereas the Pt" complexes enhanced the water solubility and the photodynamic properties of the porphyrin through a heavy atom effect.

Interaction of $\mathrm{Pt}^{\prime \prime}$ porphyrin conjugates with DNA is property necessary for dual chemo- and photo-therapy. Particularly interesting DNA sequences include G-rich DNA sequences of the telomeres at the end of chromosomes. These sequences are able to form $\mathrm{G}$-quadruplexes ( $\mathrm{G} 4$, see Figure 6 ) by $\pi-\pi$ stack-

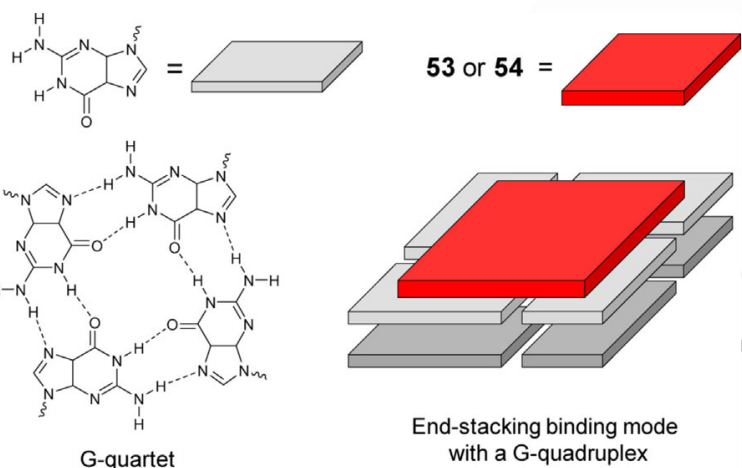

Figure 6. Structures of a G-quartet and a G-quadruplex. Illustration of the end-stacking binding mode of $\mathbf{5 3}$ or $\mathbf{5 4}$ with a G-quadruplex.
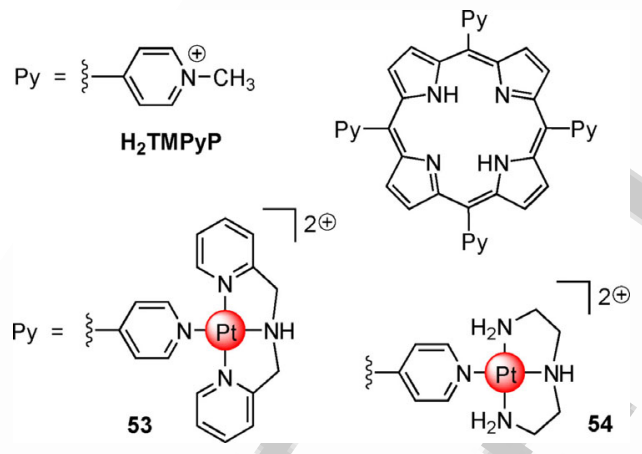

Scheme 25. Structures of $\mathbf{H}_{\mathbf{2}}$ TMPyP and Pt"-porphyrin conjugates $\mathbf{5 3}$ and $\mathbf{5 4}$.

\subsection{Porphyrins with peripheral ruthenium complexes}

Ruthenium-based compounds appear to be an attractive class of metallodrugs able to interact with DNA and proteins because they are usually less toxic than their Pt" counterparts. Moreover, ruthenium polypyridyl complexes can generate reactive oxygen species upon irradiation, leading to DNA damage. As with $\mathrm{Pt}$ " complexes, the combination of ruthenium complexes with porphyrins was investigated for dual chemo- and photo-dynamic therapy. In an early example, four $\mathrm{Ru}^{\prime}$ complexes were anchored to a free-base meso-tetrakis(4-pyridyl)porphyrin (55: Scheme 26), which was able to photoinduce oxidative cleavage and modification of DNA. ${ }^{[71]}$

The anticancer and photodynamic properties of porphyrins 56-X and 57-X functionalized with arene $\mathrm{Ru}^{\prime \prime}$ complexes were investigated as potential photosensitizing chemotherapeutic agents (Scheme 26) ${ }^{[72]}$ These complexes accumulated in Me300 melanoma cells cytoplasm and were moderately toxic in the dark $\left(\mathrm{IC}_{50} \approx 10 \mu \mathrm{M}\right.$ for $56-\mathrm{A}$ and $20 \mu \mathrm{M}$ for 56-B, 57-A and 57-B, after $72 \mathrm{~h}$ incubation). Complexes 56-A and 57-A were proven to shut down DNA synthesis by inhibiting incorporation of thymidine. Therefore, protein synthesis and cell ing of G-quartets, which are formed by four guanines assembled through complementary hydrogen bonds. These G4 structures seem to play an important role in cell aging processes. Flat cationic molecules such as $\mathbf{H}_{\mathbf{2}}$ TMPyP (Scheme 24) can stabilize G4 structures and display anticancer properties by inhibiting the activity of telomerase, an enzyme responsible for maintaining the integrity of the telomeres. Mao et al. showed that the methyl group of the pyridinium units of $\mathbf{H}_{2}$ TMPyP could be replaced by cationic Pt" complexes in clover-like compounds $\mathbf{5 3}$ and $\mathbf{5 4}$ (Scheme 25). ${ }^{[70]}$ Both compounds display high affinity for G4 structures and, more importantly, a higher selectivity for G4 rather than for double stranded DNA with an end-stacking binding mode (Figure 6). They display anticancer activities on HeLa cells by inhibiting the telomerase activity and also by repressing oncogene expression. The photodynamic properties of these compounds have not yet been investigated.
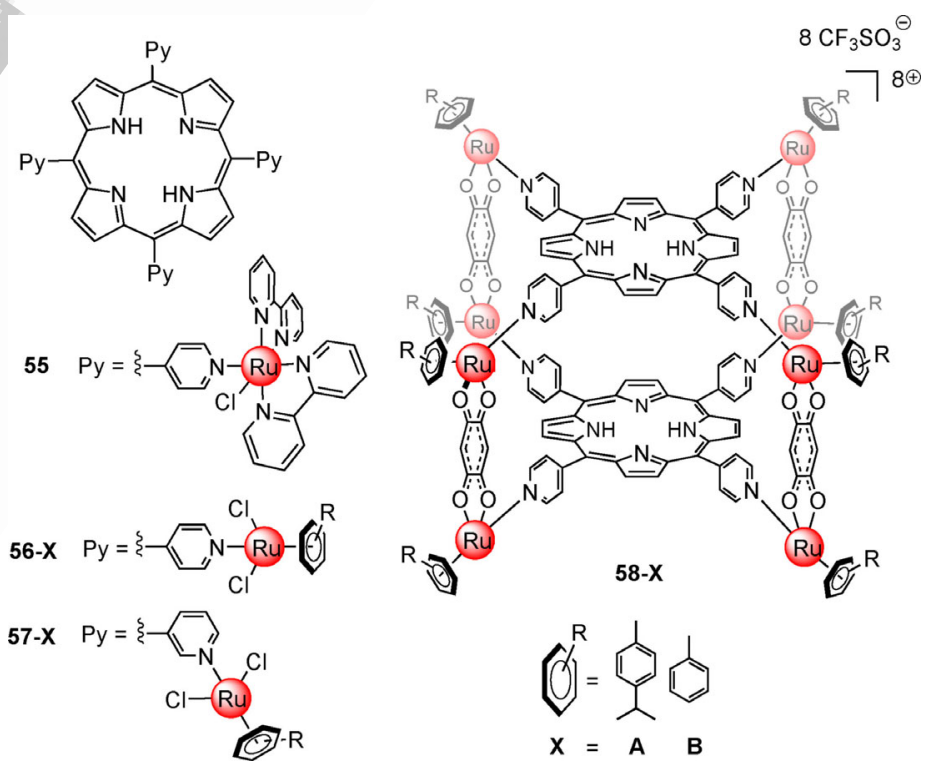

Scheme 26. Structures of Ru"-porphyrin conjugates 55-58. 
survival were diminished. Upon irradiation with red light $(\lambda=652 \mathrm{~nm})$, excellent phototoxicities were observed. Photodynamic studies revealed that $\mathrm{Ru}^{\prime \prime}$ complexes with 3-pyridyl ligands were more efficient than those with 4-pyridyl ligands. Interestingly, the same observation was made with $\mathrm{Pt}^{\prime \prime}$ complexes $\mathbf{5 1}$ and 52, suggesting that attaching the metal complexes in the meta positions of the meso aryl groups was the best choice. The potential of cationic octanuclear Ru"-porphyrin metalla-cubes 58-X for chemo- and phototherapy was also studied. ${ }^{[73]}$ Both compounds displayed excellent cytotoxicity towards melanoma cells Me300 $\left(\mathrm{IC}_{50} \approx 5\right.$ and $\approx 9 \mu \mathrm{M}$ for $58-\mathrm{A}$ and $58-\mathbf{B}$, respectively) and were more toxic than the corresponding tetra-Ru" complexes 56-A and 56B. The metalla-cubes $\mathbf{5 8 - X}$ were not toxic towards pulmonary (A549) and cervical (HeLa) cancer cells (IC50 $>70 \mu \mathrm{M})$, but exhibited good phototoxicity upon irradiation at $652 \mathrm{~nm}(\approx 75 \%$ cell death at $1 \mu \mathrm{M}$ concentration and a light dose of $10 \mathrm{~J} \mathrm{~cm}^{2}$ ).

A current focus point in the field of PDT is the use of two-photo absorption (TPA) to generate ${ }^{1} \mathrm{O}_{2}$. This technique consists in the simultaneous interaction of a PS with two photons of low energy. TPA can be

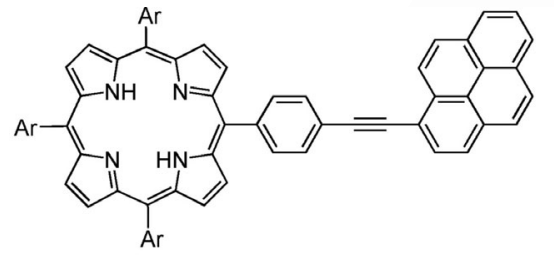
Porphyrin-pyrene $\sigma_{2}=6.1 \times 10^{5} \mathrm{GM}$ $\mathrm{Ar}=\$ \mathrm{OC}_{8} \mathrm{H}_{17}$
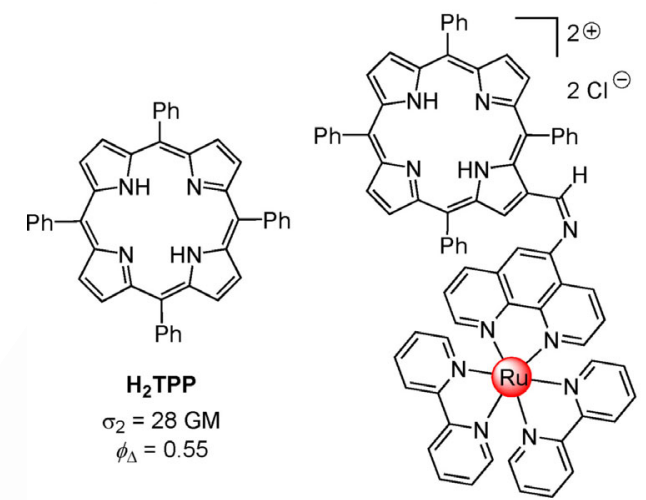

$\mathrm{H}_{\mathbf{2}} \mathrm{TPP}$
$\sigma_{2}=28 \mathrm{GM}$ $\phi_{\Delta}=0.55$

$1 \mathrm{GM}=10^{-50} \mathrm{~cm}^{4} \mathrm{~s}_{\text {photon }}-1$

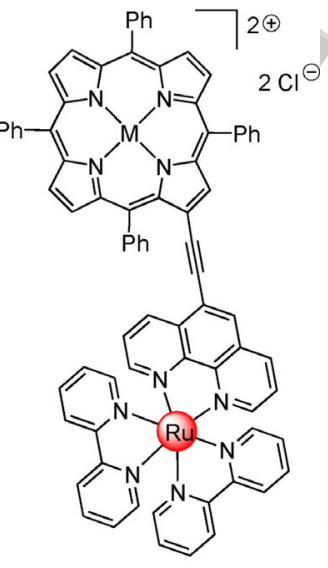

60

$\sigma_{2}=555 \mathrm{GM}$ $\phi_{\Delta}=0.76$

Scheme 27. Structures, two-photon absorption cross-sections $\sigma_{2}$ and ${ }^{1} \mathrm{O}_{2}$ quantum yields $\Phi_{\Delta}$ of $\mathrm{H}_{2} \mathrm{TPP}$, Porphyrin-pyrene and $\mathrm{Ru}^{\prime \prime}$ complexes 59 and 60 in $\mathrm{CHCl}_{3}$.

$800 \mathrm{~nm}$, which allow deeper penetration of the light through tissues. Moreover, spatial resolution of the treatment is excellent because TPA occurs at the diffraction-limited beam focus, resulting in minimal side damage along the beam path. Monomeric porphyrins have relatively low TPA cross-sections $\left(\sigma_{2}<30 \mathrm{GM}\right)$ and are not suitable PS for TPA. To increase the cross-section value of porphyrin-based sensitizers, their chemical structure can be modified by: (i) the introduction of electron-donating (D) or electron-accepting (A) groups, (ii) the extension of their $\pi$-system, or (iii) the synthesis of symmetrical $(D-\pi-D, A-\pi-A)$ or asymmetrical $(D-\pi-A)$ systems. Following this strategy, compounds with very high TPA cross-sections could be obtained $\left(\sigma_{2} \approx 6.1 \times 10^{5} \mathrm{GM}\right.$ for Porphyrin-pyrene in Scheme 27). ${ }^{[7]}$ Other candidates for TPA-PDT include the amphiphilic Ru"-porphyrin conjugates $\mathbf{5 9}$ and 60 with a hydrophilic cationic head (Ru" complex) and a hydrophobic tail (porphyrin) for enhanced cellular uptake (Scheme 27). ${ }^{[70]} \mathrm{Ru}^{\text {"I }}$ and porphyrin cores were linked together via conjugated spacers such as an acetylide ${ }^{[75 a]}$ or a Schiff base ${ }^{\text {[75b] }}$ at a $\beta$-pyrrolic position. TPA cross-sections of these $\mathrm{Ru}^{\prime \prime}$ conjugates and their ${ }^{1} \mathrm{O}_{2}$ quantum yields $\left(\Phi_{\Delta}\right)$ were significantly increased compared to those of $\mathbf{H}_{2}$ TPP (Scheme 27). These compounds were effective sensitizers for PDT under mono-photonic excitation, but were also effective under bi-photonic excitation at $\lambda_{\text {exc }}=850$ and $800 \mathrm{~nm}$ for 59 and 60 , respectively. Therefore, up to $70 \%$ of HeLa cells were killed upon laser excitation for 30 minutes (conditions of irradiation for 59: $5 \mu \mathrm{M}, 4$ hours incubation time, $\lambda_{\text {exc }}=$ $850 \mathrm{~nm}$; for $60: 1 \mu \mathrm{M}, 3$ hours incubation time, $\lambda_{\text {exc }}=$ $800 \mathrm{~nm})$.
Other Rull porphyrin conjugates were reported in the literature where the $\mathrm{Ru}^{\text {Il }}$ complex is connected to meso ary ${ }^{[76]}$ or pyridyl ${ }^{[77]}$ groups of the porphyrin. TPA cross-section values are lower due to the perpendicular orientation of the meso aryl group with respect to the porphyrin plane, preventing efficient $\pi$-conjugation between the porphyrin and the $\mathrm{Ru}^{\text {II }}$ complex (see $\mathrm{Ru}^{\text {II }}$ porphyrin conjugates 61-63 represented in Scheme 28). ${ }^{[78]}$ Interestingly, the nature of the spacers used to link Ru" complexes and porphyrins together have a strong influence on the subcellular localisation of the Ru"-porphyrin conjugates and hence, on the PDT efficiency. ${ }^{[7]}$
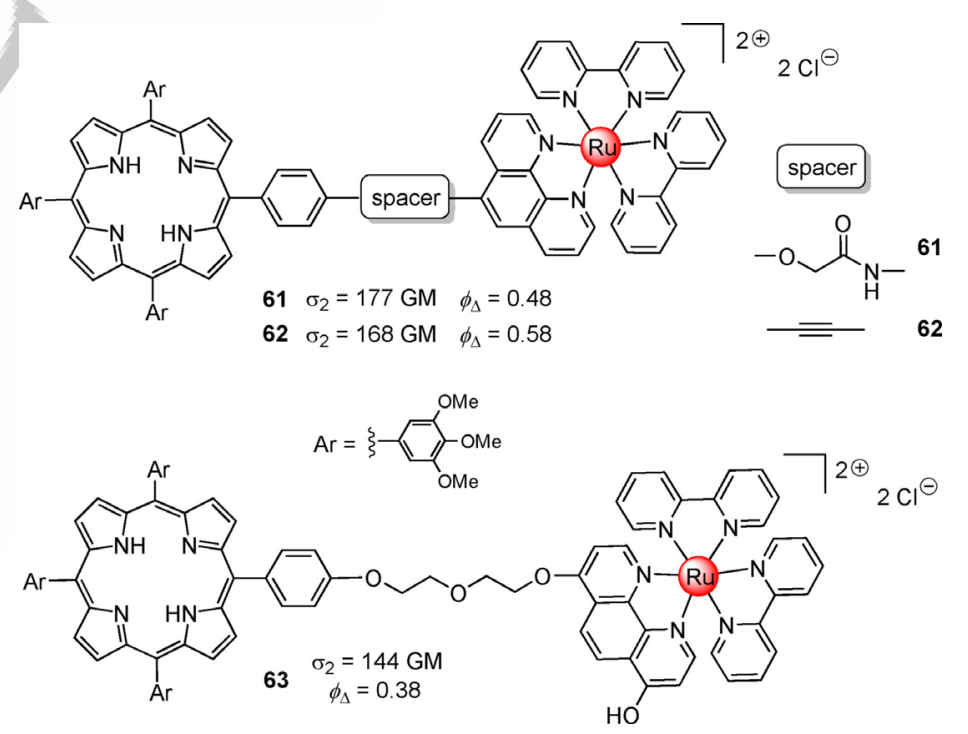

Scheme 28. Structures, two-photon absorption cross-sections $\sigma_{2}$ and ${ }^{1} \mathrm{O}_{2}$ quantum yields $\Phi_{\Delta}$ determined in $\mathrm{CHCl}_{3}$ of $\mathrm{Ru}^{\prime \prime}$-porphyrin conjugates 61-63. 


\subsection{Porphyrins with peripheral gold complexes}

Gold complexes are an interesting class of metallodrugs with a great potential for cancer therapy with modes of action different from those of platinum- or ruthenium-based drugs. Modes of action of gold metallodrugs include mitochondrial damages, inhibition of thioredoxine reductase, proteasome inhibition, and modulation of specific kinase. ${ }^{[79]}$ Although the potential of $\mathrm{Au}^{\text {III }}$ porphyrin complexes (with $\mathrm{Au}^{\text {III }}$ in the macrocycle) as anticancer agents is now quite well established (they are able to induce apoptosis and cell cycle arrest) ${ }_{r}^{[80]}$ the use of porphyrins peripherally functionalized with gold complexes is in its infancy and few examples are reported. Among these, neutral complexes 64-M porphyrins with peripheral Au'-phosphine complexes (Scheme 29$)^{[81]}$ proved to be non-toxic $\left(\mathrm{IC}_{50}>200 \mu \mathrm{M}\right)$

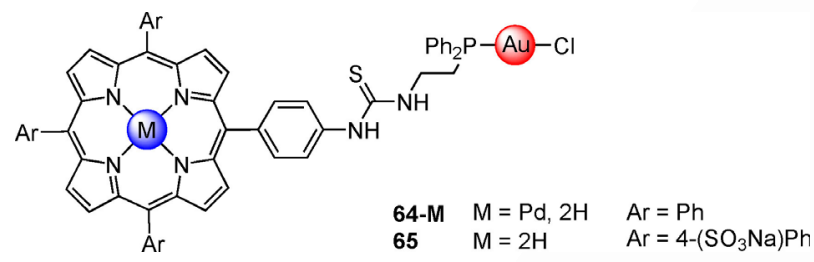

Scheme 29. Structure of $A u^{\prime}$ porphyrin conjugates $64-\mathrm{M}$ and 65 .

towards HCT116 and SW480 colon cancer cells due to their poor water solubility. The water-soluble complex 65 is more toxic, with $\mathrm{IC}_{50} \approx 56 \mu \mathrm{M}$ on HCT116 and $\approx 72 \mu \mathrm{M}$ on SW480, and the observed cytotoxicity is due to the peripheral Au' complex. The water-soluble complex 65 was also an effective PS for PDT because its cytotoxicity increased up to four times upon illumination for $\mathbf{3 0}$ minutes with white light.

Although NHCs are best known as ligands for applications in catalysis, the stability of the NHC-metal bond is an interesting property for biomedical applications to prevent the premature release of the metal ions and to improve the bioavailability of the metallodrugs. ${ }^{[82]}$ Free-base porphyrins fused to NHC-Au'-X complexes 66-68 ( $\mathrm{X}=\mathrm{Cl}$ or thiolates, see Figure 7$)$ were investigated for their photodynamic properties on MCF7 breast cancer cells. ${ }^{[83]}$ Compared to the corresponding imidazolium salt $\mathbf{8 - 2} \mathbf{H}$, the $\mathrm{Au}^{\prime}$ porphyrin complex 66 is a better photosensitizer, because the efficiency of $\mathbf{7 - 2 H}$ to generate ${ }^{1} \mathrm{O}_{2}$ is about $60 \%$ that of $\mathrm{Au}^{\prime}$ complex 66 . This difference can be attributed to the heavy atom effect exerted by the peripheral $\mathrm{Au}^{\prime}$ complex, as suggested by the lower fluorescence quantum yield and lifetime of the imidazolium salt $\mathbf{8 - 2 \mathrm { H }}$ compared to the $\mathrm{Au}^{\prime}$ porphyrin complex 66 . The synthesis of thiolato- $A u^{\prime}$ complexes 67 and $\mathbf{6 8}$ was achieved by substituting the chloride of $\mathrm{Au}^{\prime}$ complex 66 for thiolates. The Au' complex 68 is particularly interesting for targeted PDT because it contains a mannose group susceptible of targeting MCF7 breast cancer cells, which are known to overexpress mannose receptors at their surface. The mannose group also dramatically improves the solubility of compound $\mathbf{6 8}$ in water. As illustrated in Figure 7 (right side), all compounds presented limited cytotoxicity in the dark (less than $20 \%$ cell death at a concentration of $10 \mu \mathrm{M}$ ). Upon irradi-
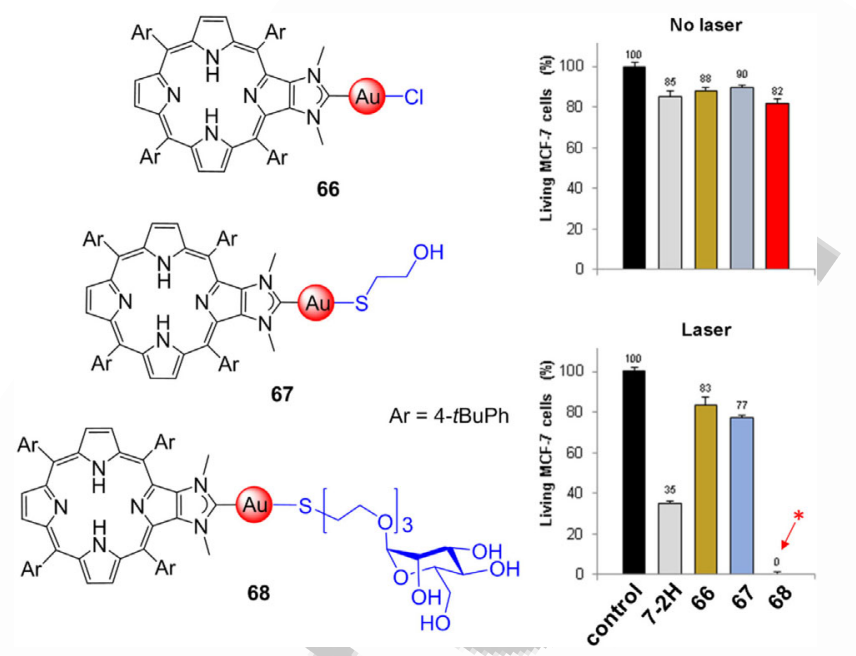

Figure 7. Left: structure of $\mathrm{Au}^{\prime}$ porphyrin complexes 66-68; Right: Cytotoxic (no laser) and photodynamic effect (laser) of imidazolium salt $\mathbf{7 - 2 \mathrm { H }}$ and $\mathrm{Au}^{\prime}$ complexes 66-68. The cells were incubated or not (control experiment in black) with $10 \mu \mathrm{m}$ of PS for $4 \mathrm{t}$ and then submitted or not to laser irradiation ( $\lambda=405 \mathrm{~nm}, 18.75 \mathrm{~J} \mathrm{~cm}^{-2}, 10 \mathrm{~min}$ ). Cells were allowed to grow for 2 days and cell viability was quantified with MTT assay. Data are mean values standard deviation from three independent experiments. *No living cells detected.

ation, imidazolium salt $\mathbf{7 - 2 \mathrm { H }}$ induced $65 \%$ cell death due to the strong interaction of cationic species like 8-2H with negatively charged cell membranes. Whereas $\mathrm{Au}^{\prime}$ complexes 66 and 67 showed limited phototoxicity, compound 68 functionalized with mannose became very toxic upon irradiation and no living MCF7 cells were detected. It was demonstrated that the mannose group of 68 promoted active endocytosis in MCF7 cells via mannose receptors. The low photodynamic effects observed with 66 and 67 may be explained by the absence of specific targeting, thus limiting active endocytosis.

\subsection{Porphyrins with peripheral gadolinium complexes}

Theranostic agents allow simultaneous imaging and therapy with a single molecular system. Therefore simple water soluble porphyrins, such as $\mathbf{H}_{\mathbf{2}}$ TMPyP (Scheme 25), and most of the peripherally metalated porphyrins presented in this section can be considered as theranostic agents. They can be detected by fluorescence imaging and, at the same time, used as a PS for PDT. Adding different imaging modalities to theranostic agents is of interest to accurately detect tumors. Magnetic resonance imaging (MRI) is a diagnostic technique offering several advantages, including an excellent spatial resolution without using ionizing radiation. MRI relies on the use of contrast agents (CAs) such as gadolinium(III) complexes. ${ }^{[84]}$ The CA improves the quality of the images by shortening the relaxation rate of protons of $\mathrm{H}_{2} \mathrm{O}$ molecules that interact with $\mathrm{Gd}^{\prime \prime \prime}$. The longitudinal relaxivity $r_{1}$ is directly related to the relaxation rate: the higher the $r_{1}$ value, the better the CA will be. In clinical use, Gd"II complexes with macrocycles like DOTA $\left(\mathrm{H}_{4} \mathrm{DOTA}=\right.$ 1,4,7,10-tetraazacyclododecane- $N, N^{\prime}, N^{\prime \prime}, N^{\prime \prime \prime}-1,4,7,10$-tetraacetic acid) or chelating ligands like diethyleneaminepentaacetate are extensively used, but have relatively low $r_{1}$ values $(\approx 3-$ 


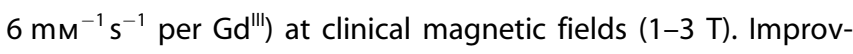
ing the $r_{1}$ value with porphyrin macrocycles was first investigated ${ }^{[85]}$ However, the inner cavity of porphyrins is too small to accommodate Gd"I adequately, and Gd"' porphyrins are too unstable for safe in vivo applications. The use of porphyrins bearing peripheral and thermodynamically stable $\mathrm{Gd}^{\text {III }}$ complexes was a better option to combine within the same framework PDT, fluorescence imaging and MRI. Moreover, synergistic effects were expected. First, Gd"I' porphyrin conjugates should present higher $r_{1}$ values compared to commercially available CAs because of their high molecular weights. Second, the hydrophilic peripheral Gd"I complexes should improve the water solubility. Finally, this hydrophilicity combined with the hydrophobic porphyrin confers an amphiphilic character to the conjugates and promotes endocytosis.

Among the $\mathrm{Gd}^{\text {III }}$ porphyrin conjugates reported in the literature, ${ }^{[85-90]}$ only those with four $\mathrm{Gd}^{\text {III }}$ at the porphyrin periphery (like those represented in Scheme 30 ) at $25^{\circ} \mathrm{C}$ and $20 \mathrm{MHz}$ are

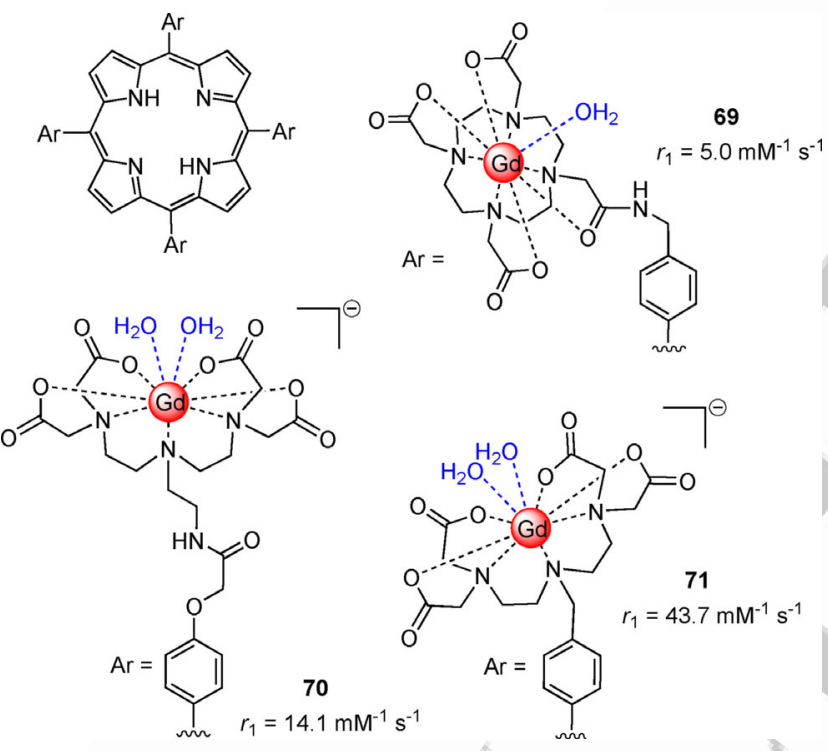

Scheme 30. Structures of Gd"' porphyrins 69-71 and corresponding relaxivities $r_{1}\left(\mathrm{~mm}^{-1} \mathrm{~s}^{-1}\right)$ per $\mathrm{Gd}^{\prime \prime \prime}$ measured at $25^{\circ} \mathrm{C}$ and $20 \mathrm{MHz}$.

discussed for better comparison. The tetranuclear Gd"I complex 69 is a free-base porphyrin bearing four meso DOTA-like Gd"I complexes. ${ }^{[87]}$ The $r_{1}$ value of $5.0 \mathrm{~mm}^{-1} \mathrm{~s}^{-1}$ per $\mathrm{Gd}^{\text {III }}$ is in the range of commercially available $\mathrm{Gd}^{\text {III }}$ based CAs. The tetranuclear Gd"I complex 70 contains diethylenetriamine$N, N, N^{\prime \prime}, N^{\prime \prime}$-tetraacetate (DTTA ${ }^{4-}$ ) as peripheral chelating sites for $\mathrm{Gd}^{\prime \prime \prime} .{ }^{[88]}$ The higher $r_{1}$ value of $14.1 \mathrm{~mm}^{-1} \mathrm{~s}^{-1}$ per Gd"I emphasizes the advantage of using such peripheral [Gd"'DTTA $]^{-}$complexes for better contrast. It is reasonable to assume that the higher $r_{1}$ value is due to the presence of two inner-sphere $\mathrm{H}_{2} \mathrm{O}$ molecules per Gd'I' as for non-porphyrinic [Gd'IITTA] ${ }^{-}$complexes $^{[89]}$ (only one $\mathrm{H}_{2} \mathrm{O}$ molecule per $\mathrm{Gd}^{\text {III }}$ in complex 69). Complex $\mathbf{7 0}$ can also be used as a PS for PDT because it is able to generate ${ }^{1} \mathrm{O}_{2}$ upon irradiation with red light $\lambda=650 \pm$ $20 \mathrm{~nm}$. For the free-base porphyrin 71 with four peripheral [Gd"IITA $^{-}$complexes (identical to those of complex 70) a very high $r_{1}$ value of $43.7 \mathrm{~mm}^{-1} \mathrm{~s}^{-1}$ per Gd $\mathrm{d}^{\text {III }}$ was observed ${ }^{[90]}$ Comparing the chemical structures of complexes $\mathbf{7 0}$ and $\mathbf{7 1}$ highlights the advantage of using a shorter and more rigid benzyl spacer instead of the longer and more flexible $\mathrm{N}$-ethyl2-phenoxyacetamide. Complex 71 produces ${ }^{1} \mathrm{O}_{2}$ in high yield $\left(\Phi_{\Delta}=0.45\right.$ in $\left.\mathrm{H}_{2} \mathrm{O}\right)$ and kills $50 \%$ of Hela cancer cells upon irradiation with red light (incubation with $6 \mu \mathrm{m}$ of 71 for 24 hours, $\lambda=635 \mathrm{~nm}$, light dose $=21 \mathrm{Jcm}^{-2}$ ). These compounds are all promising theranostic agents for future biomedical applications.

\section{Summary and Outlook}

Continuous synthetic efforts to synthesize new chromophores have led to innovative porphyrin derivatives containing peripheral coordination sites in addition to their classical inner cavity. Numerous homo- and hetero-multimetallic species have been reported during the last twenty years. Initially, many of these beautiful structures were seen as laboratory curiosities without clearly identified applications. However, combining the optic and electronic properties of porphyrins with the electronic, catalytic or biological properties of metal complexes can lead to compounds with enhanced or new properties.

In the field of catalysis, the peripheral metal complex can play the role of the catalytic site and the resulting catalytic activity may be finely tuned by the porphyrin macrocycle. Axial coordination to inner metal also offers an additional opportunity to develop supramolecular catalysts or to perform dual catalysis (both inner and outer metals are catalytic sites and play complementary roles). Moreover, the porphyrin core can be used as a light-harvesting unit for molecular photocatalytic systems, thus avoiding the use of traditional Ru- or Ir-based photoredox catalysts.

Porphyrins bearing peripheral coordination sites are suitable building blocks for the synthesis of dimers or oligomers of porphyrins linked by metal ions. Depending of the peripheral ligands and the assembling metal ions, strong electronic communication between the porphyrins was observed both in the ground and in the excited states.

Beside catalysis, peripherally metalated porphyrins have biomedical applications because they offer a suitable combination or properties for dual chemo- and photodynamic therapy. For some compounds presented in this review, the overall observed benefit is due to synergistic effects between the porphyrin and the peripheral metal complexes: the porphyrin improves the cellular uptake of the metal complexes, while the latter may improve the water solubility and/or the photodynamic properties. Additional imaging modes such as MRI (Gd"II) may also be considered to develop new theranostics.

This summary highlighted the potential of peripherally metalated porphyrins for catalysis, biomedicine and molecular electronics. We presume that other applications, such as molecular sensors, will be considered in the future. One of the next challenges is the synthesis of porphyrins with peripheral non-noble metal complexes, since Pd, Pt and Ru have been mainly used up until now. Such compounds might be interesting for applications in (photo)catalysis or biomedicine. 


\section{Acknowledgements}

The authors are grateful to the Universities of Montpellier and Strasbourg, the CNRS and the French Ministry of Research for financial support. JW and JAW thank the JST-ANR grant ANR14-JTIC-0002-01 (MECANO) and the Incoming International Master program of IdEx (Univ. of Strasbourg) for further support. R.R. is grateful for financial support from the FRC-Labex CSC (ANR-10-LABX-0026 CSC). S.R. is also grateful for financial support from the ANR (ANR-09-JCJC-0089-01: PORPH-NHC), the Région Languedoc-Roussillon (Research Grant "Chercheur(se)s d'Avenir -2015-005984) and the FEDER program (Fonds Européen de Développement Régional). Serge Bertrand is acknowledged for his help on the illustrations.

\section{Conflict of interest}

The authors declare no conflict of interest.

Keywords: antitumour agents • catalysis - molecular electronics $\cdot$ photochemistry $\cdot$ porphyrinoids

[1] J. Deisenhofer, O. Epp, K. Miki, R. Huber, H. Michel, Nature 1985, 318, $618-624$

[2] R. N. Pittman in Regulation of Tissue Oxygenation, Chapter 4-Oxygen Transport (Eds.: D. N. Granger, J. Granger), Morgan \& Claypool Publishers Life Science series, 2011, pp. 19-30.

[3] P. R. Ortiz de Montellano in Cytochrome P450: Structure, Mechanism, and Biochemistry Chapter 4-Substrate Oxidation by Cytochrome P450 Enzymes (Eds.: P. R. Ortiz de Montellano), Springer, 2015, pp. 111-176.

[4] a) X. Chi, A. J. Guerin, R. A. Haycock, C. A. Hunter, L. D. Sarson, J. Chem. Soc. Chem. Commun. 1995, 2563-2565; b) R. Takahashi, Y. Kobuke, J. Am. Chem. Soc. 2003, 125, 2372-2373; c) A. Tsuda, T. Nakamura, S. Sakamoto, K. Yamaguchi, A. Osuka, Angew. Chem. Int. Ed. 2002, 41, 2817 2821; Angew. Chem. 2002, 114, 2941 -2945; d) I.-W. Hwang, T. Kamada, T. K. Ahn, D. M. Ko, T. Nakamura, A. Tsuda, A. Osuka, D. Kim, J. Am. Chem. Soc. 2004, 126, 16187-16198.

[5] S. Richeter, C. Jeandon, J.-P. Gisselbrecht, R. Ruppert in Handbook of Porphyrin Science, Vol. 3 (Eds.: K. M. Kadish, K. M. Smith, R. Guilard), World Scientific, Singapore, 2010, pp. 429-483.

[6] a) A. Srinivasan, H. Furuta, Acc. Chem. Res. 2005, 38, 10-20; b) M. Toganoh, H. Furuta in Handbook of Porphyrin Science, Vol. 2 (Eds.: K. M. Kadish, K. M. Smith, R. Guilard), World Scientific, Singapore, 2010, pp. 295-367.

[7] a) P. Even, B. Boitrel, Coord. Chem. Rev. 2006, 250, 519-541; b) N. Jux in Handbook of Porphyrin Science, Vol. 24 (Eds.: K. M. Kadish, K. M. Smith, R. Guilard), World Scientific, Singapore, 2012, pp. 181-269.

[8] H. Lu, H. Jiang, Y. Hu, L. Wojtas, X. P. Zhang, Chem. Sci. 2011, 2, 2361 2366.

[9] J. L. Maxwell, K. C. Brown, D. W. Bartley, T. Kodadek, Science 1992, 256, $1544-1547$.

[10] A. Penoni, R. Wanke, S. Tollari, E. Gallo, D. Musella, F. Ragaini, F. Demartin, S. Cenini, Eur. J. Inorg. Chem. 2003, 1452-1460.

[11] B. J. Anding, A. Ellern, L. K. Woo, Organometallics 2012, 31, 3628-3635.

[12] G. Cheng, G. A. Mirafzal, L. K. Woo, Organometallics 2003, 22, $1468-$ 1474.

[13] G. S. Ananthnag, V. S. Shetti, Dalton Trans. 2017, 46, 14062-14082.

[14] B. M. J. M. Suijkerbuijk, M. Lutz, A. L. Spek, G. van Koten, R. J. M. Klein Gebbink, Org. Lett. 2004, 6, 3023-3026.

[15] B. M. J. M. Suijkerbuijk, S. D. Herreras Martínez, G. van Koten, R. J. M. Klein Gebbink, Organometallics 2008, 27, 534-542.

[16] S. Yamaguchi, T. Katoh, H. Shinokubo, A. Osuka, J. Am. Chem. Soc. 2007, $129,6392-6393$.
[17] J. Yamamoto, T. Shimizu, S. Yamaguchi, N. Aratani, H. Shinokubo, A. Osuka, J. Porphyrins Phthalocyanines 2011, 15, 534-538.

[18] K. Yoshida, T. Nakashima, S. Yamaguchi, A. Osuka, H. Shinokubo, Dalton Trans. 2011, 40, 8773-8775.

[19] R.-S. Lin, M.-R. Li, Y.-H. Liu, S.-M. Peng, S.-T. Liu, Inorg. Chim. Acta 2010 , 363, 3523-3529.

[20] Y. Matano, K. Matsumoto, T. Shibano, H. Imahori, J. Porphyrins Phthalocyanines 2011, 15, 1172-1182.

[21] J.-F. Lefebvre, D. Leclercq, J.-P. Gisselbrecht, S. Richeter, Eur. J. Org. Chem. 2010, 1912-1920.

[22] J.-F. Lefebvre, J.-F. Longevial, K. Molvinger, S. Clément, S. Richeter, C. $R$ Chimie 2016, 19, 94-102.

[23] A. V. Astakhov, O. V. Khazipov, A. Y. Chernenko, D. V. Pasyukov, A. S Kashin, E. G. Gordeev, V. N. Khrustalev, V. M. Chernyshev, V. P. Ananikov, Organometallics 2017, 36, $1981-1992$.

[24] J.-F. Lefebvre, M. Lo, J.-P. Gisselbrecht, O. Coulembier, S. Clément, S. Richeter, Chem. Eur. J. 2013, 19, 15652-15660.

[25] J.-F. Lefebvre, M. Lo, D. Leclercq, S. Richeter, Chem. Commun. 2011, 47 $2976-2978$.

[26] K. Fujimoto, T. Yoneda, H. Yorimitsu, A. Osuka, Angew. Chem. Int. Ed. 2014, 53, 1127-1130; Angew. Chem. 2014, 126, 1145-1148.

[27] B. M. J. M. Suijkerbuijk, D. J. Schamhart, H. Kooijman, A. L. Spek, G. van Koten, R. J. M. Klein Gebbink, Dalton Trans. 2010, 39, 6198-6216.

[28] Y. Miyazaki, C. Kahlfuss, A. Ogawa, T. Matsumoto, J. A. Wytko, K. Oohora, T. Hayashi, J. Weiss, Chem. Eur. J. 2017, 23, 13579-13582.

[29] V. F. Slagt, M. Röder, P. C. J. Kamer, P. W. N. M. van Leeuwen, J. N. H. Reek, J. Am. Chem. Soc. 2004, 126, 4056-4057.

[30] C. K. Prier, D. A. Rankic, D. W. C. MacMillan, Chem. Rev. 2013, 113, 5322 5363.

[31] a) K. L. Skubi, T. R. Blum, T. P. Yoon, Chem. Rev. 2016, 116, 10035-10074; b) B. L. Tóth, O. Tischler, Z. Novák, Tetrahedron Lett. 2016, 57, 45054513; c) X. Lang, J. Zhao, X. Chen, Chem. Soc. Rev. 2016, 45, 3026- 3038.

[32] K. Rybicka-Jasińska, W. Shan, K. Zawada, K. M. Kadish, D. Gryko, J. Am. Chem. Soc. 2016, 138, 15451-15458.

[33] C. Matlachowski, B. Braun, S. Tschierlei, M. Schwalbe, Inorg. Chem. 2015, $54,10351-10360$

[34] a) C. D. Windle, M. V. Câmpian, A.-K. Duhme-Klair, E. A. Gibson, R. N. Perutz, J. Schneider, Chem. Commun. 2012, 48, 8189-8191; b) C. D. Windle, M. W. George, R. N. Perutz, P. A. Summers, X. Zhong Sun, A. C. Whitwood, Chem. Sci. 2015, 6, 6847-6864.

[35] B. Gholamkhass, H. Mametsuka, K. Koike, T. Tanabe, M. Furue, O. Ishitani, Inorg. Chem. 2005, 44, 2326-2336.

[36] P. Zhang, M. Wang, C. Li, X. Li, J. Dong, L. Sun, Chem. Commun. 2010, 46, 8806-8808.

[37] K. Peuntinger, T. Lazarides, D. Dafnomili, G. Charalambidis, G. Landrou, A. Kahnt, R. P. Sabatini, D. W. McCamant, D. T. Gryko, A. G. Coutsolelos, D. M. Guldi, J. Phys. Chem. C 2013, 117, 1647-1655.

[38] P. Lang, J. Habermehl, S. I. Troyanov, S. Rau, M. Schwalbe, Chem. Eur. J. 2018, 24, 3225-3233.

[39] C. M. Drain, J.-M. Lehn, J. Chem. Soc. Chem. Commun. 1994, 2313-2315.

[40] C. M. Drain, F. Nifiatis, A. Vasenko, J. D. Batteas, Angew. Chem. Int. Ed. 1998, 37, 2344-2347; Angew. Chem. 1998, 110, 2478-2481.

[41] R. D. Hartnell, D. P. Arnold, Organometallics 2004, 23, 391- 399.

[42] S. Richeter, A. Hadj-Aïssa, C. Taffin, A. van der Lee, D. Leclercq, Chem Commun. 2007, 2148-2150.

[43] M. Abdelhameed, P.-L. Karsenti, A. Langlois, J.-F. Lefebvre, S. Richeter, R. Ruppert, P. D. Harvey, Chem. Eur. J. 2014, 20, 12988-13001.

[44] S. Richeter, C. Jeandon, R. Ruppert, H. J. Callot, Chem. Commun. 2001 91-92.

[45] S. Richeter, C. Jeandon, J.-P. Gisselbrecht, R. Ruppert, H. J. Callot, J. Am. Chem. Soc. 2002, 124, 6168-6179.

[46] H. Higuchi, K. Shimizu, J. Ojima, K.-I. Sugiura, Y. Sakata, Tetrahedron Lett. 1995, 36, 5359-5362.

[47] V. S.-Y. Lin, S. G. DiMagno, M. J. Therien, Science 1994, 264, 1105-1111.

[48] A. Tsuda, H. Furuta, A. Osuka, J. Am. Chem. Soc. 2001, 123, 1030410321.

[49] S. Richeter, C. Jeandon, J.-P. Gisselbrecht, R. Graff, R. Ruppert, H. J. Callot, Inorg. Chem. 2004, 43, 251-263.

[50] H. Dekkiche, A. Buisson, A. Langlois, P.-L. Karsenti, L. Ruhlmann, P. D. Harvey, R. Ruppert, Inorg. Chem. 2016, 55, 10329-10336. 
[51] S. Richeter, C. Jeandon, J.-P. Gisselbrecht, R. Ruppert, H. J. Callot, Inorg. Chem. 2007, 46, $10241-10251$.

[52] a) S. Richeter, C. Jeandon, R. Ruppert, H. J. Callot, Chem. Commun. 2002 266-267; b) S. Richeter, C. Jeandon, C. Sauber, J.-P. Gisselbrecht, R. Ruppert, H. J. Callot, J. Porphyrins Phthalocyanines 2002, 6, 423-430; c) M. A. Carvalho, H. Dekkiche, L. Karmazin, F. Sanchez, B. Vincent, M. Kanesato, Y. Kikkawa, R. Ruppert, Inorg. Chem. 2017, 56, $15081-15090$.

[53] S. Yamaguchi, T. Katoh, H. Shinokubo, A. Osuka, J. Am. Chem. Soc. 2008, 130, 14440-14441.

[54] a) Y. Matano, K. Matsumoto, Y. Nakao, H. Uno, S. Sakaki, H. Imahori, J. Am. Chem. Soc. 2008, 130, 4588-4589; b) Y. Matano, K. Matsumoto, H. Hayashi, Y. Nakao, T. Kumpulainen, V. Chukharev, N. V. Tkachenko, H. Lemmetyinen, S. Shimizu, N. Kobayashi, D. Sakamaki, A. Ito, K. Tanaka, H. Imahori, J. Am. Chem. Soc. 2012, 134, 1825-1839.

[55] Y.-J. Chen, S.-S. Chen, S.-S. Lo, T.-H. Huang, C.-C. Wu, G.-H. Lee, S.-M. Peng, C.-Y. Yeh, Chem. Commun. 2006, 1015-1017.

[56] N. Fukui, H.-W. Jiang, A. Osuka, Org. Chem. Front. 2017, 4, 767-772.

[57] J. R. Durrant, G. Hastings, D. M. Joseph, J. Barber, G. Porter, D. R. Klug, Proc. Natl. Acad. Sci. USA 1992, 89, 11632-11636.

[58] A. Harriman, F. Odobel, J.-P. Sauvage, J. Am. Chem. Soc. 1994, 116, $5481-5482$.

[59] D. Bellows, S. M. Aly, C. P. Gros, M. El Ojaima, J.-M. Barbe, R. Guilard, P. D. Harvey, Inorg. Chem. 2009, 48, 7613-7629.

[60] M. Abdelhameed, A. Langlois, P.-L. Karsenti, S. Richeter, R. Ruppert, P. D. Harvey, Chem. Commun. 2014, 50, 14609-14612.

[61] H. S. Cho, D. H. Jeong, M.-C. Yoon, Y. H. Kim, Y.-R. Kim, D. Kim, S. C. Jeoung, S. K. Kim, N. Aratani, H. Shinmori, A. Osuka, J. Phys. Chem. A 2001, 105, 4200-4210.

[62] H. Dekkiche, A. Buisson, A. Langlois, P.-L. Karsenti, L. Ruhlmann, R. Ruppert, P. D. Harvey, Chem. Eur. J. 2016, 22, 10484-10493.

[63] S. Hatz, J. D. Lambert, P. R. Ogilby, Photochem. Photobiol. Sci. 2007, 6, $1106-1116$.

[64] S. Hatz, L. Poulsen, P. R. Ogilby, Photochem. Photobiol. 2008, 84, $1284-$ 1290.

[65] R. Song, Y.-S. Kim, C. O. Lee, Y. S. Sohn, Tetrahedron Lett. 2003, 44, 1537 1540.

[66] a) H. Brunner, K.-M. Schellerer, B. Treittinger, Inorg. Chim. Acta 1997, 264, 67-79; b) C. Lottner, K.-C. Bart, G. Bernhardt, H. Brunner, J. Med. Chem. 2002, 45, 2064-2078; c) H. Brunner, K.-M. Schellerer, Inorg. Chim. Acta 2003, 350, 39-48; d) C. Lottner, R. Knuechel, G. Bernhardt, H. Brunner, Cancer Lett. 2004, 203, 171-180; e) C. Lottner, R. Knuechel, G. Bernhardt, H. Brunner, Cancer Lett. 2004, 215, 167-177.

[67] a) C. Lottner, K.-C. Bart, G. Bernhardt, H. Brunner, J. Med. Chem. 2002, 45, 2079-2089; b) H. Brunner, N. Gruber, Inorg. Chim. Acta 2004, 357, $4423-4451$.

[68] A. Naik, R. Rubbiani, G. Gasser, B. Spingler, Angew. Chem. Int. Ed. 2014, 53, 6938-6941; Angew. Chem. 2014, 126, 7058-7061.

[69] T. T. Tasso, T. M. Tsubone, M. S. Baptista, L. M. Mattiazzi, T. V. Acunha, B. A. Iglesias, Dalton Trans. 2017, 46, 11037-11045.

[70] X.-H. Zheng, Q. Cao, Y.-L. Ding, Y.-F. Zhong, G. Mu, P. Z. Qin, L.-N. Ji, Z.W. Mao, Dalton Trans. 2015, 44, 50-53.

[71] J. Onuki, A. V. Ribas, M. H. G. Medeiros, K. Araki, H. E. Toma, L. H. Catalani, P. Di Mascio, Photochem. Photobiol. 1996, 63, 272-277.

[72] a) F. Schmitt, P. Govindaswamy, G. Süss-Fink, W. H. Ang, P. J. Dyson, L. Juillerat-Jeanneret, B. Therien, J. Med. Chem. 2008, 51, 1811-1816; b) F. Schmitt, P. P. Govindaswamy, O. Zava, G. Süss-Fink, L. Juillerat-Jeanneret, B. Therien, J. Biol. Inorg. Chem. 2009, 14, 101-109.

[73] F. Schmitt, N. P. E. Barry, L. Juillerat-Jeanneret, B. Therien, Bioorg. Med. Chem. Lett. 2012, 22, 178-180.
[74] N. Sheng, D. Liu, J. Wu, B. Gu, Z. Wang, Y. Cui, Dyes Pigm. 2015, 119, $116-121$.

[75] a) J. X. Zhang, K.-L. Wong, W.-K. Wong, N.-K. Mak, D. W. J. Kwong, H.-L. Tam, Org. Biomol. Chem. 2011, 9, 6004-6010; b) H. Ke, W. Ma, H. Wang G. Cheng, H. Yuan, W.-K. Wong, D. W. J. Kwong, H.-L. Tam, K.-W. Cheah, C.-F. Chan, K.-L. Wong, J. Lumin. 2014, 154, 356-361.

[76] a) T. Gianferrara, A. Bergamo, I. Bratsos, B. Milani, C. Spagnul, G. Sava, E. Alessio, J. Med. Chem. 2010, 53, 4678-4690; b) J. Pan, L. Jiang, C.-F Chan, T.-H. Tsoi, K.-K. Shiu, D. W. J. Kwong, W.-T. Wong, W.-K. Wong, K.-L. Wong, J. Lumin. 2017, 184, 89-95.

[77] a) T. Gianferrara, B. Serli, E. Zangrando, E. lengo, E. Alessio, New. J. Chem 2005, 29, 895-903; b) P. Sweigert, Z. Xu, Y. Hong, S. Swavey, Dalton Trans. 2012, 41, $5201-5208$.

[78] J.-X. Zhang, J.-W. Zhou, C.-F. Chan, T. C.-K. Lau, D. W. J. Kwong, H.-L. Tam, N.-K. Mak, K.-L. Wong, W.-K. Wong, Bioconjugate Chem. 2012, 23, $1623-$ 1638.

[79] S. Nobili, E. Mini, I. Landini, C. Gabbiani, A. Casini, L. Messori, Med. Res. Rev. 2010, 30, 550-580.

[80] a) A. D. Lammer, M. E. Cook, J. L. Sessler, J. Porphyrins Phthalocyanines 2015, 19, 398-403; b) Y. Wang, Q.-Y. He, R. W.-Y. Sun, C.-M. Che, J.-F Chiu, Cancer Res. 2005, 65, 11553-11564.

[81] S. Tasan, C. Licona, P.-E. Doulain, C. Michelin, C. P. Gros, P. Le Gendre, P. D. Harvey, C. Paul, C. Gaiddon, E. Bodio, J. Biol. Inorg. Chem. 2015, 20, $143-154$

[82] M.-L. Teyssot, A.-S. Jarrousse, M. Manin, A. Chevry, S. Roche, F. Norre, C. Beaudoin, L. Morel, D. Boyer, R. Mahiou, A. Gautier, Dalton Trans. 2009, 6894-6902.

[83] J.-F. Longevial, K. El Cheikh, D. Aggad, A. Lebrun, A. van der Lee, F. Tielens, S. Clément, A. Morère, M. Garcia, M. Gary-Bobo, S. Richeter, Chem. Eur. J. 2017, 23, 14017-14026.

[84] a) E. Tóth, A. E. Merbach in The Chemistry of Contrast Agents in Medical Magnetic Resonnance Imaging, 2nd ed. (Eds.: J. Wiley and Sons), New York, 2013, Relaxivity of Gadolinium(III) Complexes, pp. 25-82, Chap. 2; b) P. Caravan, Chem. Soc. Rev. 2006, 35, 512-523; c) E. Terreno, D. D. Castelli, A. Viale, S. Aime, Chem. Rev. 2010, 110, 3019-3042.

[85] M. J. F. Calvete, S. M. A. Pinto, M. M. Pereira, C. F. G. C. Geraldes, Coord Chem. Rev. 2017, 333, 82-107.

[86] a) C. P. Gros, A. Eggenspiller, A. Nonat, J.-M. Barbe, F. Denat, MedChem Comm 2011, 2, 119-125; b) J. Schmitt, V. Heitz, A. Sour, F. Bolze, P. Kessler, L. Flamigni, B. Ventura, C. S. Bonnet, E. Tóth, Chem. Eur. J. 2016, 22, 2775-2786.

[87] A. Eggenspiller, C. Michelin, N. Desbois, P. Richard, J.-M. Barbe, F. Denat, C. Licona, C. Gaiddon, A. Sayeh, P. Choquet, C. P. Gros, Eur. J. Org. Chem. 2013, 6629-6643.

[88] J. Luo, L.-F. Chen, P. Hu, Z.-N. Chen, Inorg. Chem. 2014, 53, 4184-4191.

[89] A. Sour, S. Jenni, A. Ortí-Suárez, J. Schmitt, V. Heitz, F. Bolze, P. Loureiro de Sousa, C. Po, C. S. Bonnet, A. Pallier, E. Tóth, B. Ventura, Inorg. Chem. 2016, 55, 4545-4554

[90] a) J. B. Livramento, E. Tóth, A. Sour, A. Borel, A. E. Merbach, R. Ruloff, Angew. Chem. Int. Ed. 2005, 44, 1480-1484; Angew. Chem. 2005, 117, 1504-1508; b) J. Costa, E. Tóth, L. Helm, A. E. Merbach, Inorg. Chem. 2005, 44, 4747-4755.

Manuscript received: March 9, 2018

Revised manuscript received: April 23, 2018

Accepted manuscript online: April 24, 2018

Version of record online: $\mathbf{\square} \mathbf{\square}, 0000$ 


\section{REVIEW}

Please provide a short (ca. 500 characters) text that highlights the work to accompany the graphic provided for the Table of Contents

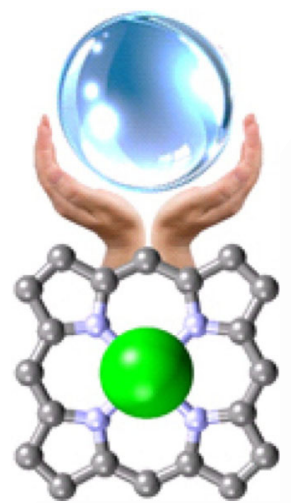

Antitumour Agents

J.-F. Longevial, S. Clément, J. A. Wytko, R. Ruppert, J. Weiss, S. Richeter*

\section{$\mathbf{\square}-\mathbf{\square}$}

Peripherally Metalated Porphyrins with Applications in Catalysis, Molecular Electronics and Biomedicine

Please provide a short (700-1000 characters characters) text that highlights the work to accompany the graphic provided for the Frontispiece

Please check that the ORCID identifiers listed below are correct. We encourage all authors to provide an ORCID identifier for each coauthor. ORCID is a registry that provides researchers with a unique digital identifier. Some funding agencies recommend or even require the inclusion of ORCID IDs in all published articles, and authors should consult their funding agency guidelines for details. Registration is easy and free; for further information, see http:/orcid.org/.

Dr. Jean-François Longevial

Dr. Sébastien Clément

Dr. Jennifer A. Wytko

Dr. Romain Ruppert

Dr. Jean Weiss

Dr. Sébastien Richeter http://orcid.org/0000-0001-5284-0931 